\title{
Eastern Motifs in the Ornamentation of Eighteenth-Century Siberian Church Architecture
}

\author{
William C. Brumfield* \\ Tulane University \\ New Orleans, Louisiana, USA
}

Received 19.12.2015, received in revised form 21.01.2016, accepted 24.02.2016

Russia's engagement with Asian peoples and cultures forms a topic whose boundaries have yet to be thoroughly explored, particularly in the relationship between Russian and Asian architecture. As an artifact demanding significant resources as well as building skills, architecture involves numerous factors related to social, cultural, economic and technological history. The present article will point to specific instances, primarily in eighteenth-century Siberian church architecture that suggest a Russian receptivity to east Asian ornamentation. Russia is a Eurasian power, and it is plausible that the growth of trade between Russia and eastern Asia (especially China) in the eighteenth century would have fostered possibilities for cultural transference. Such exchange, it will be argued, seems to have occurred in the realm of architecture, in which decorative motifs could be observed, disseminated (even in printed form) and copied at significant points along Russia's Asian pathways.

Keywords: Siberian church architecture, Baroque architecture, Tobolsk, Irkutsk, Eniseisk, Buriatiia, Krasnoiarsk, Buddhist visual culture, Russo-Chinese trade, Ivan Bechevin.

DOI: 10.17516/1997-1370-2016-9-4-745-774.

Research area: culture studies.

Russia's engagement with Asian peoples and cultures forms a topic whose boundaries have yet to be thoroughly explored, particularly in the relationship between Russian and Asian architecture. As an artifact demanding significant resources as well as building skills, architecture involves numerous factors related to social, cultural, economic and technological history. The present article will not attempt to give a detailed examination of this broader range of Russo-Asian relations, but will point to specific instances, primarily in eighteenth-century Siberian church architecture that suggest a Russian receptivity to east Asian ornamentation. Russia is a Eurasian power, and it is plausible that the growth of trade between Russia and eastern Asia (especially China) in the eighteenth century would have fostered possibilities for cultural transference. Such exchange, it will be argued, seems to have occurred in the realm of architecture, in which decorative motifs could be observed, disseminated (even in printed form) and copied at significant points along Russia's Asian pathways.

Indeed, it would appear that this receptivity was encouraged by the highly ornamental styles of Muscovite and Ukrainian "baroque" church

(C) Siberian Federal University. All rights reserved

* Corresponding author E-mail address: william.brumfield@gmail.com 
architecture brought to Siberia by church prelates and builders from Ukraine and the Russian north in the early eighteenth century. Precisely this Russo-Ukrainian tendency toward facade ornamentation, which lasted in "Siberian baroque" architecture throughout the eighteenth century, created a tolerance for decorative motifs ${ }^{1}$. In this environment sources for such motifs might include the shrines, or stupas, of east Asian Buddhist culture. As will be seen below, certain Siberian ornamental figures clearly reflect Buddhist art. In other examples, such as steeply elevated profiled window pediments, the possibility of Asian derivation is based on the formal resemblance to stupa forms and to devotional objects such as metal Buddhist lamps ${ }^{2}$.

Of course various interpretations are possible for the homomorphic characteristics of certain decorative figures in this study. And there are numerous examples of complex ogival window pediments in Russian church architecture of the seventeenth century, such as the Church of the Twelve Apostles in the Moscow Kremlin. However, the window pediments of certain eighteenth-century Siberian churches have a particularly sharp and elevated "fiery" form reminiscent of Buddhist iconographic and decorative forms. It seems that the decisive factor resides in taxonomic details of the resemblance.
Furthermore, the presence of Buddhist motifs (for example, the Dharma wheel) on the facades of such monuments as the Church of the Elevation of the Cross in Irkutsk demonstrates that such motifs were accepted in Siberian church design at a certain period in the eighteenth century. It must be emphasized, however, that the presence of these figures in no way implied a challenge to Orthodox dogma or an assimilation of Buddhism qua religia. Indeed, their inclusion as part of decorative façade might be seen as an aspect of an Orthodox missionary projection among the indigenous population.

Although the most obvious examples of this tendency occur in eastern Siberia, we will suggest that the appearance of Asian decorative motifs occurred relatively early in western Siberian cities such as Tobolsk. This is plausible because of the role that Tobolsk played as the "capital" of Siberia for much of the eighteenth century. Indeed, we know at least one case in which the same builders were present in both Tobolsk and Irkutsk at this early stage of masonry construction in Siberia. For example, one of the oldest historic buildings of Tobolsk is the Church of the Miraculous Image of the Savior (Nerukotvornyi Spas). Severely damaged during the Soviet period (Fig. 1), the church was built to the north of the kremlin in 1709-13 and is similar in some details to the

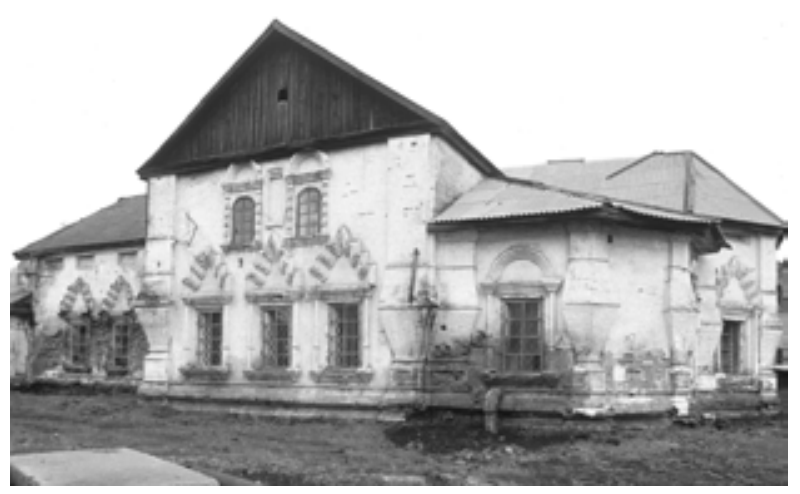

Fig. 1. Tobolsk. Church of the Miraculous Image of the Savior (Nerukotvornyi Spas), south facade. All photographs by the author 
contemporary Savior Church in Irkutsk (see below). In form and ornament it represents a combination of seventeenth-century Muscovite design--the geometrically imprecise ground plan, the heavy but visually impressive brickwork--and flamboyant decorative motifs ${ }^{3}$.
The most visible elements on the facade of the Savior Church are the high ogival pediments (often referred to as "fiery," because of their resemblance to flames) above the main windows (Fig. 2). A similar motif appeared on the northeast chapel of the Trinity Church in Tiumen (Fig. 3),

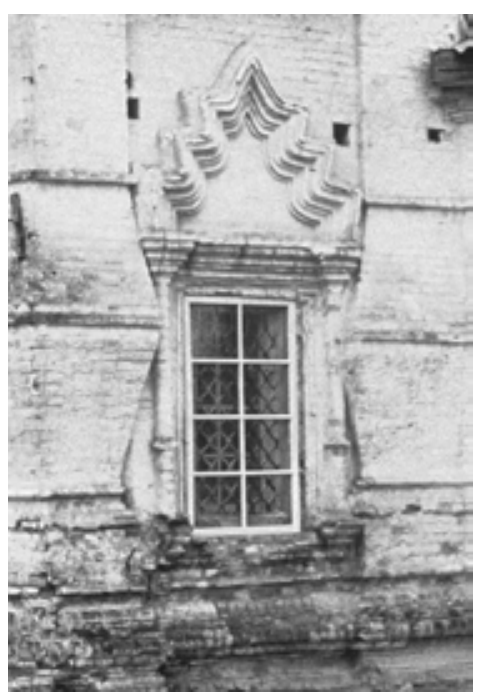

Fig. 2. Tobolsk. Church of the Miraculous Image of the Savior (Nerukotvornyi Spas), east facade, window detail

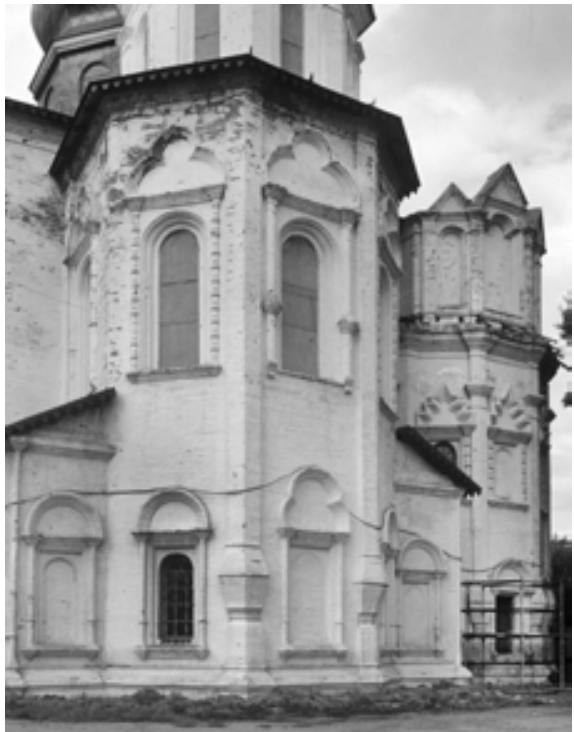

a

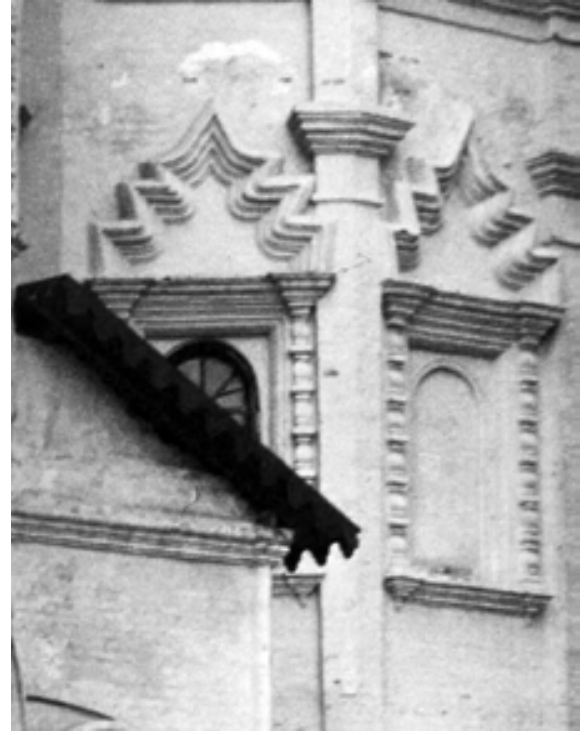

b

Fig. 3. Tiumen. Trinity Monastery, Cathedral of the Trinity, east facade with apse and north chapel (a), north chapel window surrounds (b) 
constructed at the same time and probably by masons supervised by the same master, Matvei Maksimov of Tobolsk ${ }^{4}$. Although there is as yet no clear explanation for the appearance of this motif, the general outline bears a resemblance to the tapering vertical form of the stupa (suburgan) in Buddhist architecture of south and East Asia, including Mongolia. (See Fig. 35). One could even note the crown of flames that often appears above the head of the Buddha. (See Fig. 36). Almost all major Siberian settlements were in some way connected by trading contacts with East Asia, and this elaborate ogival design appears on eighteenth-century churches throughout eastern Siberia, from Yeniseisk to the Transbaikal area ${ }^{5}$.

Eastern motifs are particularly rich in the church architecture of Irkutsk, located on the banks of the Angara River, a tributary of the Yenisei. After various attempts to found a winter base on the Angara during the 1650s, a log fort was constructed in 1661 on the eventual site of Irkutsk, at the confluence of the Angara and Irkut Rivers $^{6}$. The original purpose of the settlement was to establish Russian authority and trade with the region's aboriginal Buriats. Additional forts were built in 1668-69, and Irkutsk grew rapidly by virtue of its favorable location among them. In 1686 it gained the status of town, and shortly thereafter began sending caravans to China, which ultimately became an important source of trade and cultural influence for Irkutsk?

By the beginning of the eighteenth century, Irkutsk, whose $\log$ fort had been rebuilt in 1670, was rapidly becoming the undisputed administrative and commercial center of eastern Siberia. One of the clearest signs of this growing importance is the number of large masonry churches, which made Irkutsk one of the most significant centers of church design in Siberia, rivaled only by Tobolsk in western Siberia ${ }^{8}$. Their profusion of decorative styles and varied forms combined Russian and Ukrainian influences with motifs that in some cases seem derived from Asian (Buddhist) sources.

Moscow, of course, played a central role in defining the forms of religious architecture in Siberia, but the pioneering culture of the Russian north in towns such as Vologda, Totma, Velikii Ustiug, and Solvychegodsk may also have provided inspiration for the churches of Irkutsk ${ }^{9}$. The construction surge during the middle of the eighteenth century gave rise to a rich urban silhouette created by the positioning of churches, with their vertical accents of cupolas and towers, along the streets and riverbanks of Irkutsk ${ }^{10}$.

This process unfolded with special creativity in eighteenth-century Irkutsk monuments such as the Church of the Miraculous Icon of the Savior (Fig. 4), whose basic design reflects the parish architecture of Moscow and Yaroslavl at the end of the seventeenth century. For its time, this is a rare example of an attributed structure, built by the architect Moisei Ivanovich Dolgikh, a descendant of Moscow brick masons. Experienced masons were a rarity in Siberia, and the state Siberian Office (Sibirskii prikaz) created in Verkhotur'e and Tobolsk a base of cadres who could be sent to other Siberian towns. Archival evidence indicates that Dolgikh had joined one of the earliest groups of master builders (podmaster'ia) sent to Siberia-specifically, Tobolsk--in $1687^{11}$. Having spent ten years at work on the large ensemble surrounding the Sophia Cathedral in Tobolsk, Dolgikh apparently returned to Moscow without official leave from Tobolsk, worked an additional five years in Moscow, and concluded a new contract with the voevoda in Verkhotur' ${ }^{12}$. From there he was sent to Irkutsk in 1701.

Construction of the Savior Church--situated at the south wall of the fort near the Angara River-began in 1706 with support from the voevoda A. I. Siniavin and the townspeople. In 1710 the two-story cuboid structure was completed and its 


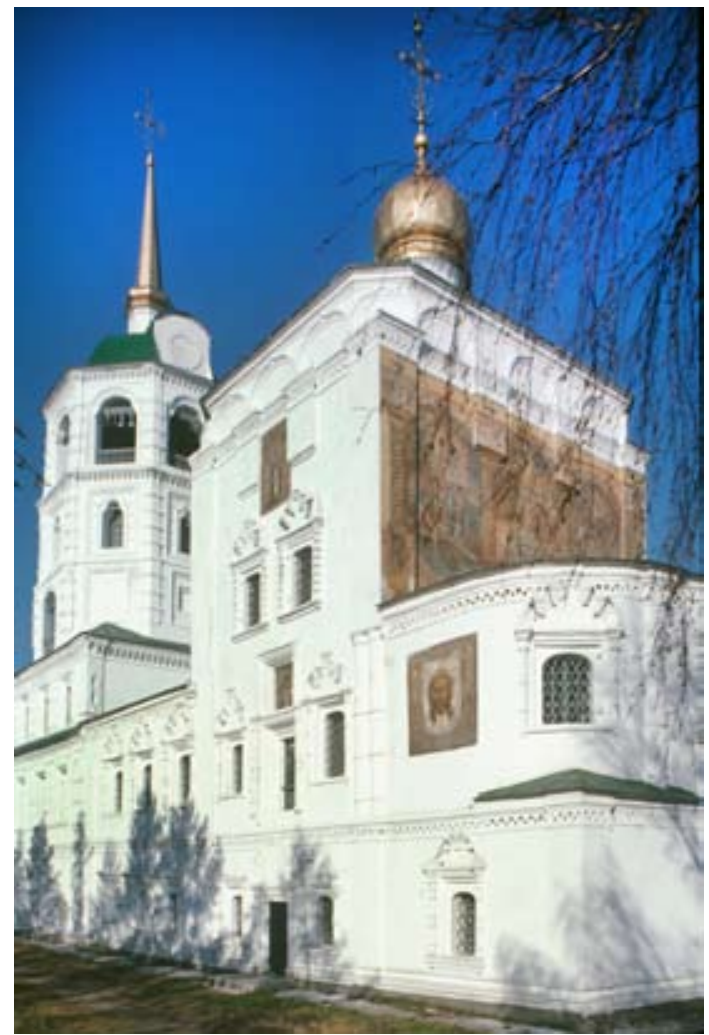

Fig. 4. Irkutsk. Church of the Miraculous Image of the Savior (Nerukotvornyi Spas), southeast view

primary altar consecrated by Varlaam, the first bishop to serve in Irkutsk ${ }^{13}$. Of the new church's two stories the lower was originally used in traditional Russian fashion as a storehouse for fur pelts and other valuables until 1713, when a second altar, dedicated to Saint Nicholas, was consecrated for winter services in this space ${ }^{14}$. The surrounds of the main windows on all facades culminate in the vertical, "flaring" pediments similar to those of the Church of the Savior in Tobolsk (Fig. 5). Indeed, this is the earliest known appearance of these forms in eastern Siberian architecture. The dominant component of the Church of the Savior appeared almost half a century later with the construction of a bell tower at the west end of the vestibule in 1758-62. Its massive octagonal form, which literally overshadows the rest of the church, rises from a cuboid base that also contains two altars.
A distinctive feature of the Savior Church is its exterior frescoes. (Fig. 6) Originally painted in tempera at the beginning of the nineteenth century and subsequently repainted in oil, the frescoes are located on the south and east facades ${ }^{15}$. While the former portray sacred images of Saint Mitrofan of Voronezh, Saint Nicholas, and, the Miraculous Image of the Savior (on the south facade of the apse), the east wall above the apsidal structure is divided into three large scenes: the Procession of the Cross into the Water (often interpreted as the baptism of the Buriats), the Baptism of Christ (in the center), and the Sanctification of Innokentii Kul'chitskii, first bishop of the Eparchy of Irkutsk and Nerchinsk.

Although such exterior frescoes are unique in Siberia and rare in Russian church architecture generally, there is a possible predecessor in the large exterior fresco of Christ Pantokrator on the 


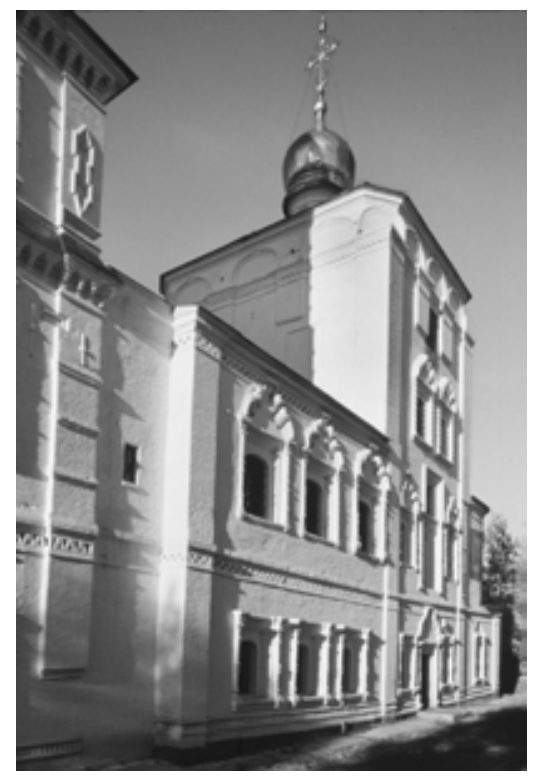

a

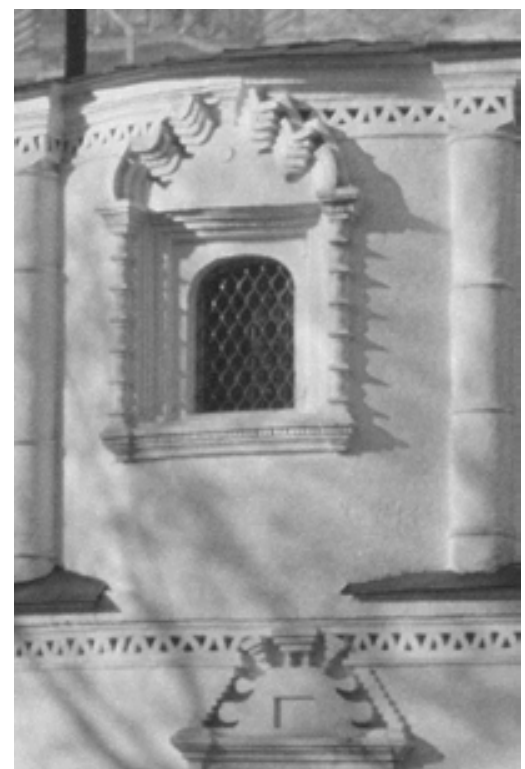

b

Fig. 5. Irkutsk. Church of the Miraculous Image of the Savior (Nerukotvornyi Spas), south facade with window surrounds (a), east facade, apse window (b)

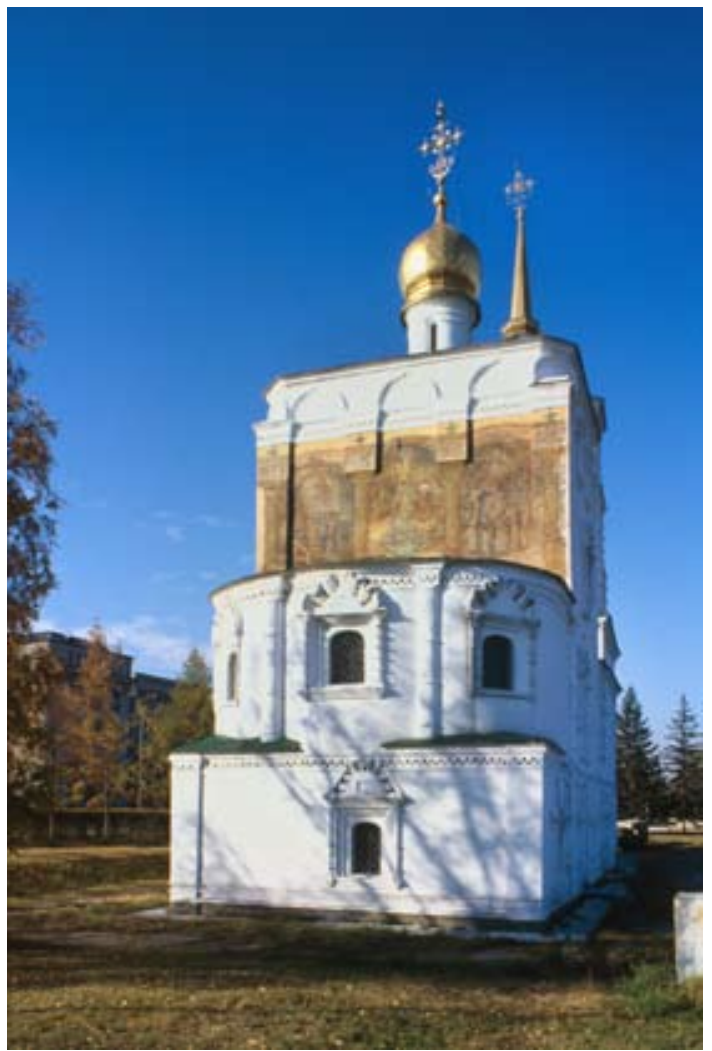

Fig. 6. Irkutsk. Church of the Miraculous Image of the Savior (Nerukotvornyi Spas), east view, apse with frescoes on east wall 
east wall of the Church of Saint Dmitrii (170009) at Dymkova Sloboda near Velikii Ustiug ${ }^{16}$. As elsewhere in Siberia, the connections between Velikii Ustiug and early Irkutsk were many, and included not only the contributions of explorers and skilled artisans, but also the spiritual traditions of the Russian north. In that regard it is worth noting that in 1703 settlers from Velikii Ustiug built one of Irkutsk's earliest churches, dedicated to Saints Prokopii and Ioann of Ustiug ${ }^{17}$. And although the possible influence of the Dymkovo fresco could only have occurred later, the links between the two areas continued throughout the eighteenth century.

By the middle decades of the eighteenth century, Irkutsk advanced to a new level of commercial importance in Siberia. Not only was the majority of its population involved in entrepreneurial activity of one form or another, but its merchantry assumed an increasingly important role in guiding the city--particularly in the absence of an established local nobility ${ }^{18}$. Although the state administration of Catherine the Great still ruled with a strong hand and provided few meaningful guarantees of individual rights, eighteenth-century Irkutsk demonstrates the relative freedom within which private initiative developed in certain parts of Siberia, as opposed to European Russia with its more rigid social structure based on serfdom.

The details of Irkutsk's economic growth would require a separate study, but the 1760 s held a special significance with the development of the Moscow Road, more reliable in comparison with the earlier network of trails, rivers, and portages from Eniseisk. Irkutsk's status as a major administrative and economic center for Siberia gained new recognition with the establishment in 1764 of Irkutsk guberniia, including for a time Yakutiia, the Far East, and even Alaska. And in 1768 the state sanctioned annual trade fairs in Irkutsk, which further strengthened the city's position as the leading center of commerce in Siberia, with trade extending from the Orient to European Russia. Although Kiakhta was the main point of entry for the China trade, Irkutsk was the channel through which almost all these goods--including tea--were transshipped ${ }^{19}$.

This surge of economic vitality led to the construction of new buildings, such as a large Merchants Court (gostinnyi dvor; not extant), begun in 1778 to a plan attributed to the prominent Saint Petersburg architect Giacomo Quarenghi. But the wealth of Irkutsk was also reflected in its churches, whose construction had been supported by merchants from the town's earliest days ${ }^{20}$. This is not merely an issue of financial largesse, for it would appear that merchant patronage underlies the distinctive architectural ornamentation of Irkutsk churches, with their suggestion of oriental elements combined with features from European Russia. As one Russian historian has noted in regard to mid-eighteenth century Irkutsk: "The newly wealthy merchantry invests large amounts in the construction of a whole series of major, richly-decorated churches that within a short space of time replace earlier wooden churches. Merchants frequently supervised the erection of these churches, as a result of which the artistic qualities of the buildings depended, apparently, not only on the client--the clergy--but also on the merchantry. The tastes of the latter not infrequently were formed under the influence of contact with the peoples of Siberia and the Orient" ${ }^{21}$.

This meeting of cultures is particularly evident in one of the most interesting masonry buildings erected in Siberia during the eighteenth century, the Church of the Elevation of the Cross, built in stages between 1747 and 1760 on the Hill of the Cross. From its bell tower and steeple over the west end to its panoply of Ukrainian-style domes over the vestibule and main sanctuary in the east, this church remains even now a 


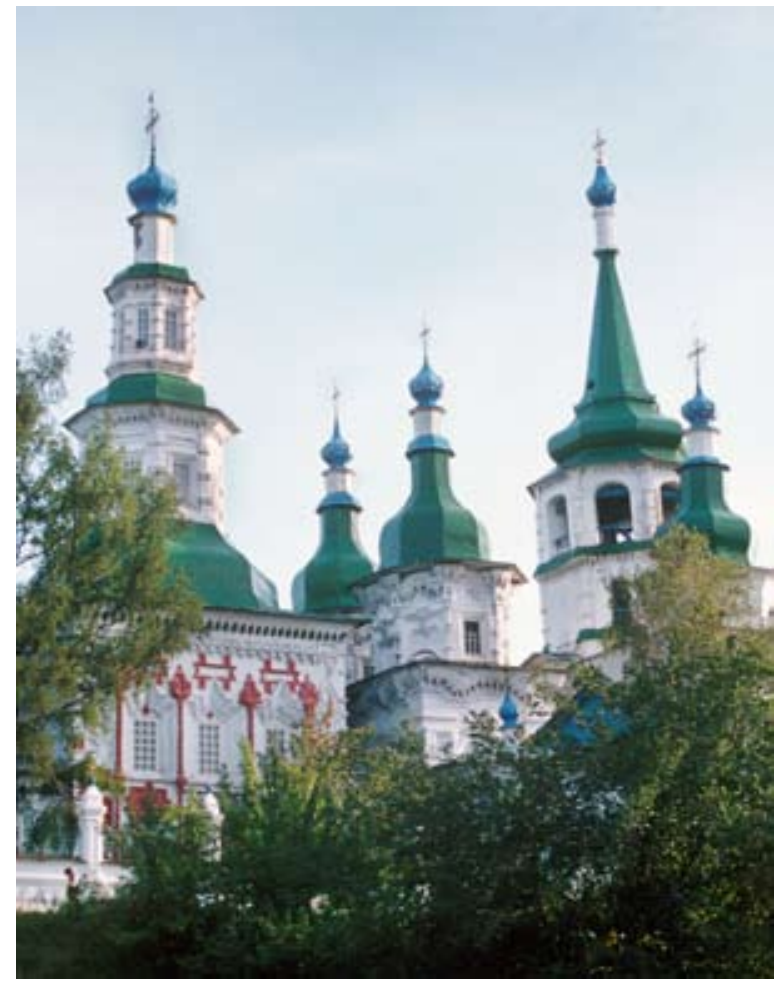

Fig. 7. Irkutsk. Church of the Elevation of the Cross, north view

dominant presence in the southern part of historic Irkutsk (Fig. 7). Its site had earlier been occupied by a log church constructed in 17171719 and dedicated to the Trinity and to Saint Sergius of Radonezh. In 1740 Fedor Shcherbakov, a merchant with important connections in foreign trade, petitioned the eparchy to rebuild the church in brick, but his request was denied. A subsequent petition by Ivan Amosov, a local entrepreneur and craftsman, was approved by the church in $1746^{22}$. Although documentary evidence concerning the church donors is lacking, it is known that at least two of Amosov's sons enrolled in a masons' guild during the time of construction, and it is therefore possible that they were the primary builders, if not patrons, of the church ${ }^{23}$.

As with its log predecessor, the main altar of the new church was originally consecrated to the Trinity in 1758 . Other altars of what was then known as the Trinity Church were dedicated to the Elevation of the Cross, the Dormition, and Saint Sergius of Radonezh. In 1779 the donations of two merchants led to the construction of a large chapel attached to the north facade, and in 1860 the architect Vladislav Kudel'skii constructed a large narthex at the west end of the church. In 1867 the main altar was reconsecrated to the Elevation of the Cross, which henceforth became the name of the church ${ }^{24}$.

For the structural center of the Church of the Elevation of the Cross, there are obvious connections not only with the Siberian variations on traditional Orthodox parish architecture in European Russia (the basic cuboid structure with no interior piers), but also with the vertical vaulting systems of the Ukrainian baroque (Fig. 8). At the same time the Church of the Elevation of the Cross interprets this legacy in ways that reflect the building traditions of the Russian north and 


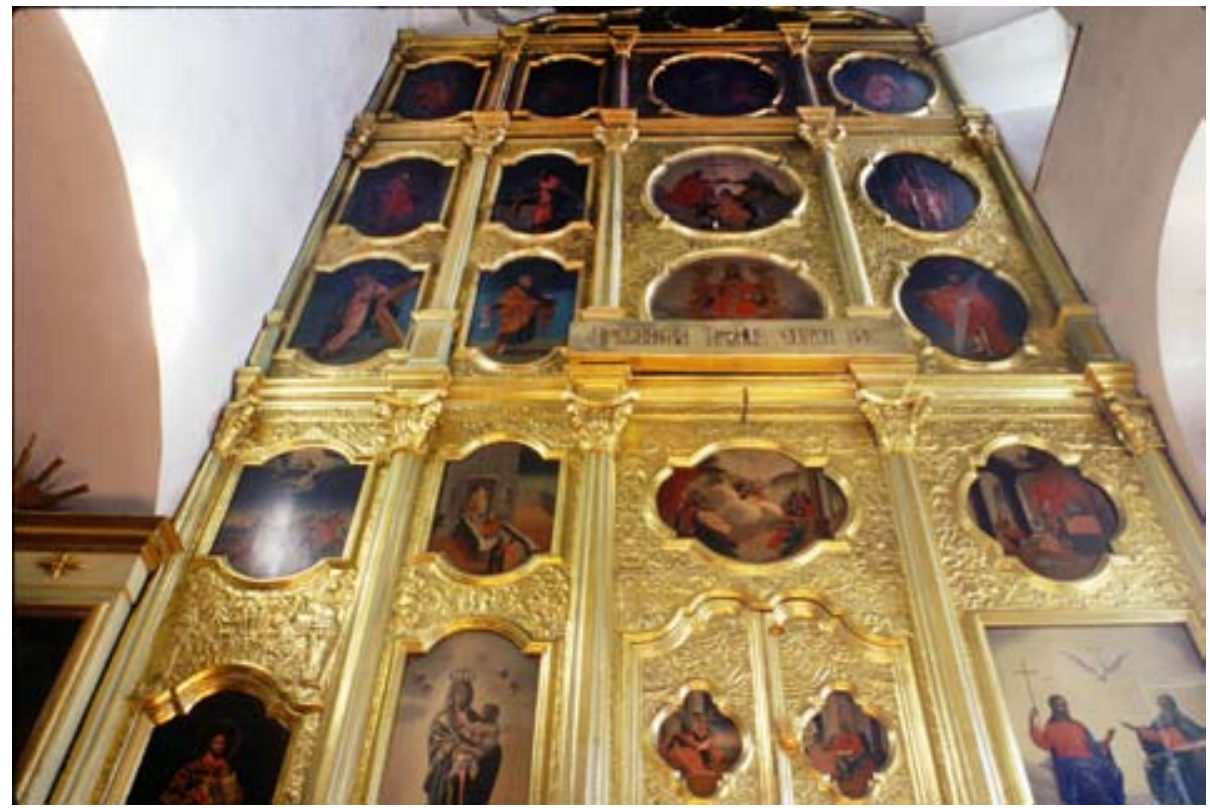

Fig. 8. Irkutsk. Church of the Elevation of the Cross, iconostasis

the Urals, from Sol'vychegodsk to Solikamsk and Verkhotur'e ${ }^{25}$.

Yet closer inspection of the facade ornamentation of the Church of the Elevation of the Cross, which has been carefully restored (Fig. 9), shows presence of Buddhist motifs such as the terra cotta images of the sacred Dharma wheel (Fig. 10) on the north and south facades. (See Fig. 37 for an example of a Dharma wheel-the Eightfold Path--on a nineteenth-century Buriat temple). There are also intricate stupa-like forms in terra cotta framing the north and south portals. (Fig. 11) And on the corners of the main structure there are relief outlines of ornamental figures that suggest humanoid forms, including the presence of a large heart (Fig. 12).

Although the origins of the above motifs have not been precisely defined, it seems that the active trade between Irkutsk and China played a role in the design of this cross-cultural work of art. Furthermore, it is not unlikely that Indian temple motifs were accessible through the caravan routes. In this respect the involvement of the merchant Fedor Shcherbakov in the design of the church should not be ruled out, despite his unsuccessful petition of 1740 .

Russian art historians have long noted the oriental character of Irkutsk church architecture, without providing specific details as to sources. Igor Grabar, for example, in his pioneering History of Russian Art (1909) compared the facade (Fig. 13) of the Church of the Elevation of the Cross to an elaborate eastern carpet ${ }^{26}$. It is also known that craftsmen from the region's Buriat populations participated in local church construction in the eighteenth century ${ }^{27}$, although masonry Buddhist temples in Buriat areas did not appear until the early nineteenth century.

All of these strands, from Ukraine to the Orient, contributed to the tapestry that has been called by some the "Siberian baroque" 28 . Whatever the validity of this term--which derives more closely from the intricate facade decorations of the late seventeenth-century "Moscow baroque" style than from baroque architecture as understood in central Europe 


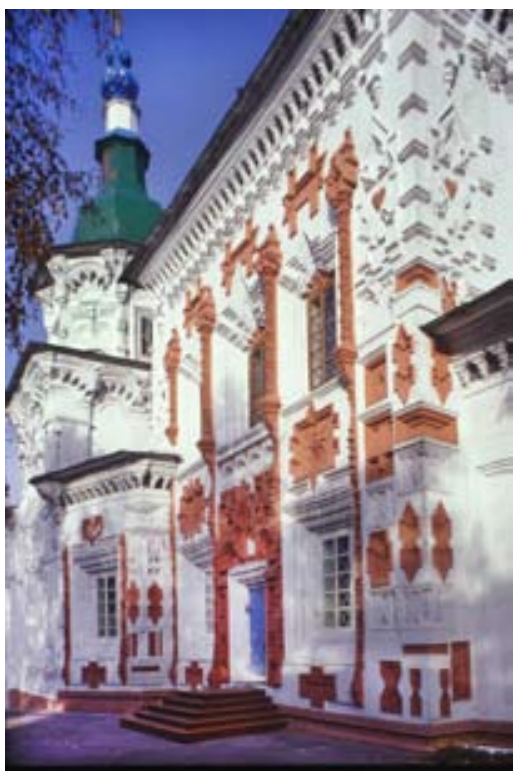

a

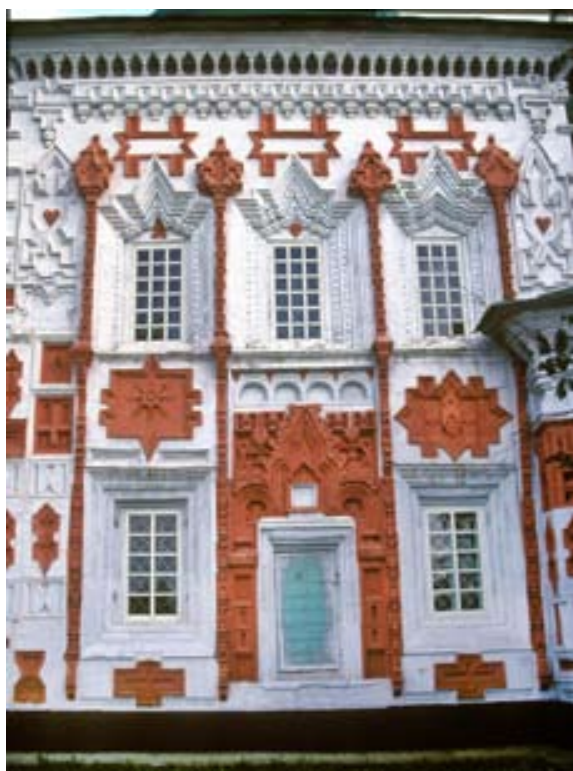

b

Fig. 9. Irkutsk. Church of the Elevation of the Cross, south facade (a), north facade with ornamental motifs (b)

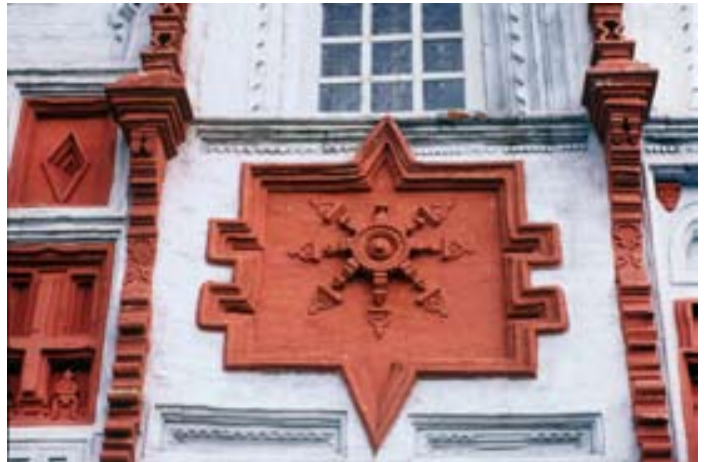

Fig. 10. Irkutsk. Church of the Elevation of the Cross, north facade ornamental motif (Dharma wheel, Eightfold Path)

and Saint Petersburg--it is a convenient way of signifying the unusual ornamental character of eighteenth-century Siberian church architecture. Even within this designation, there are significant regional differences, as is clear from a comparison of late eighteenth-century churches in Tobolsk with churches from the same period in Irkutsk.

The distinctive Irkutsk ornamental style is richly elaborated on the façades of the Church

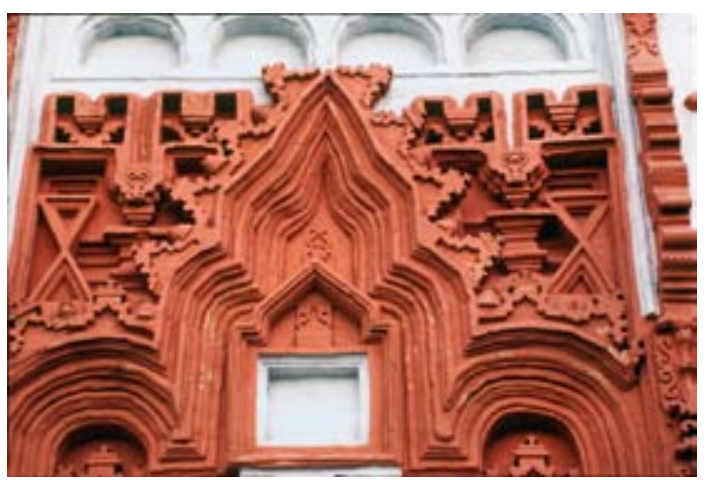

Fig. 11. Irkutsk. Church of the Elevation of the Cross, north facade, portal decoration

of the Trinity. Built on the site of a log church dating from 1718-1721, the brick Trinity Church was begun in the 1750s (the precise year is undocumented), with one altar consecrated in 1763. A collapse of the vaulting, however, delayed completion until the 1770s, and the entire church was dedicated only in 1778 (Fig. 14). Although the Church of the Trinity shows similarities with the decorative programs of earlier monuments 


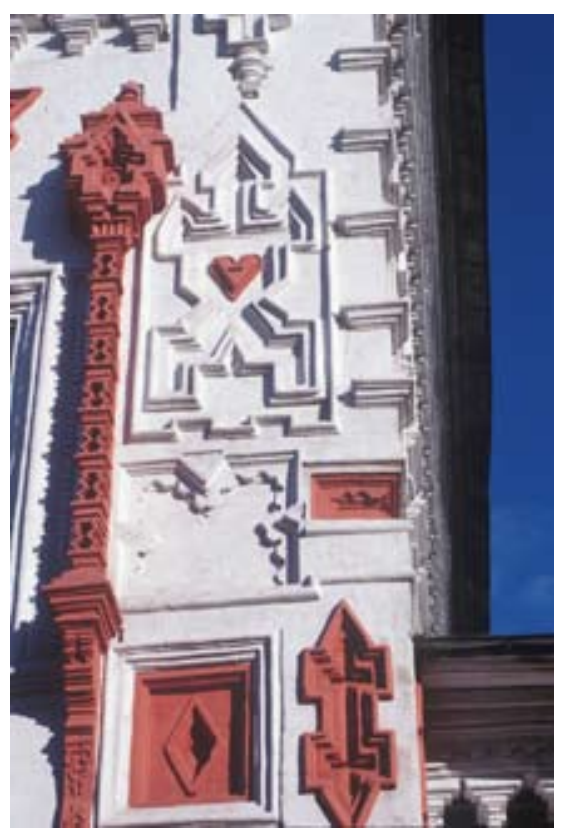

Fig. 12. Irkutsk. Church of the Elevation of the Cross, south facade, east corner decorative figures (including heart motif)

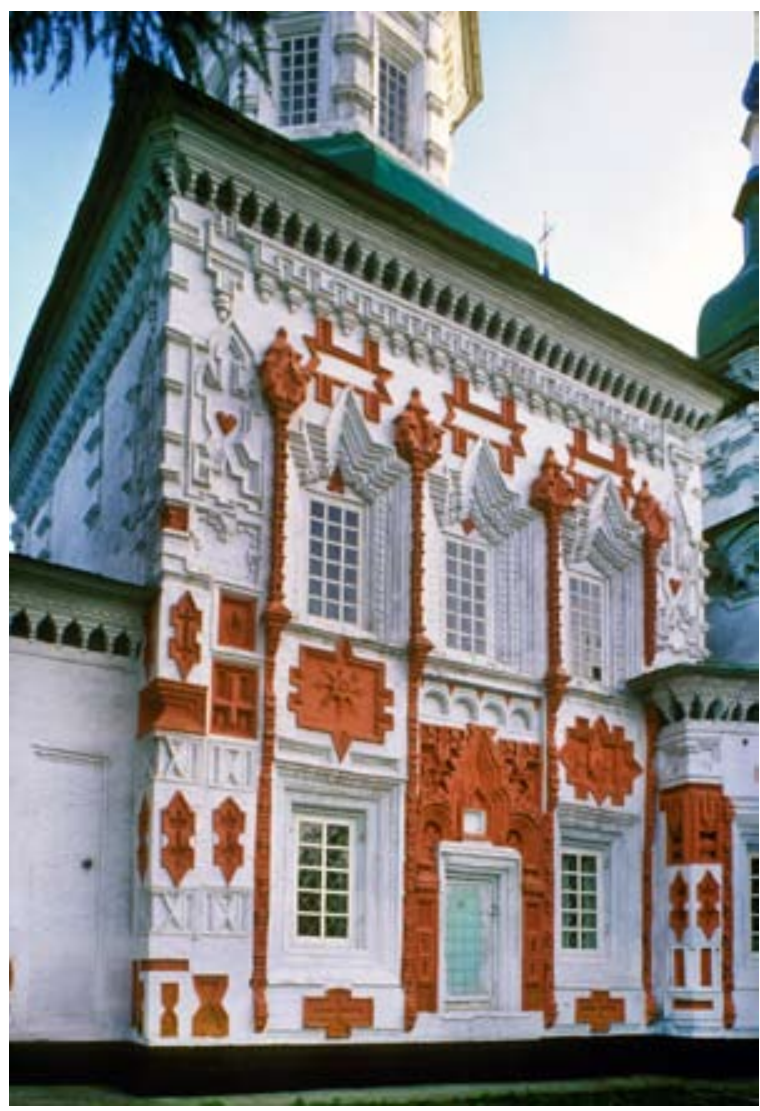

Fig. 13. Irkutsk. Church of the Elevation of the Cross, north facade 


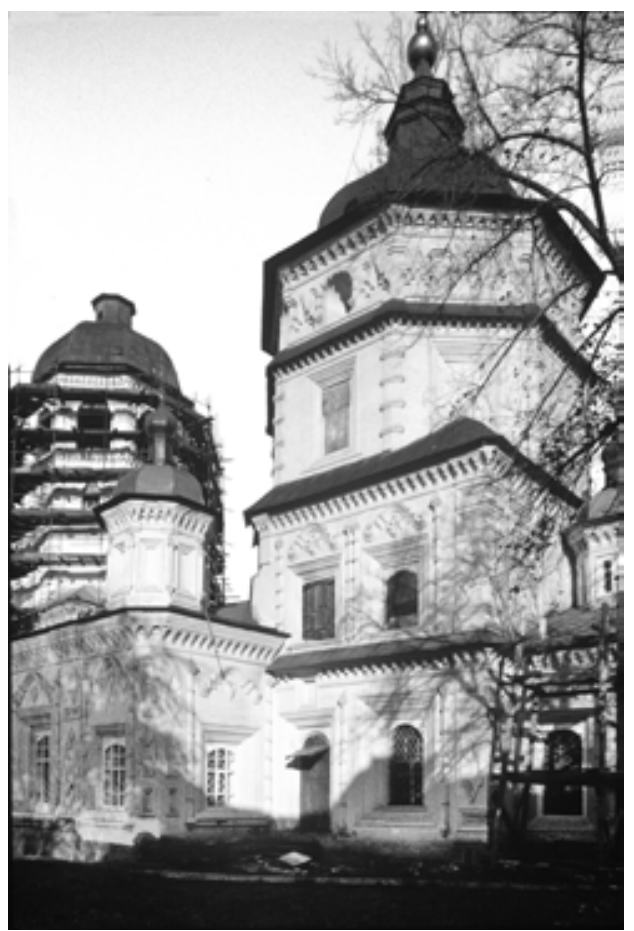

Fig. 14. Irkutsk. Church of the Trinity, southeast view

such as the Church of the Savior and the Church of the Elevation of the Cross, its overall design shows greater unity--the result of a single project, however prolonged. The main sanctuary is contained within a unified space that ascends without piers from a cuboid structure to an octagonal form. This bold geometric composition is echoed in the bell tower on the west end. The link between the two towers is a vestibule or refectory (trapeza), whose wide proportions accommodated two additional altars. All parts of the structure are decorated, yet the unusual decorative motifs are particularly evident on the upper levels (Fig. 15). The window surrounds, ornamental gables, and corner pilasters enhance the rich plasticity of the church's structure, particularly in sunlight ${ }^{29}$.

Similar ornamental motifs appear on the bell tower of the Church of the Icon of the Virgin of the Sign at Znamenskii Convent, one of the oldest religious foundations in Irkutsk ${ }^{30}$.
In the usual practice, the original church was of logs, constructed in 1693 and again in 1727. Three decades later the Irkutsk merchant Ivan Bechevin, who held a lucrative liquor monopoly from the state, received permission from the consistory administration to donate funds for the construction of a masonry church at the convent ${ }^{31}$. the Znamenskii Convent church was completed by1762 (Fig. 16). Two subsequent building stages, also supported by private donations, created altar chapels on the south (1770-73) and on the north (1791-94) ${ }^{32}$. The decoration of the main cuboid structure of the church combines seventeenth-century dentilation on the cornices with simple window surrounds capped by inverted volutes known as "curls"--a feature of late eighteenthcentury church decoration in the Urals and western Siberia (Fig. 17). The octagonal bell tower follows the traditional form for Irkutsk churches but also displays the eight-spoke 


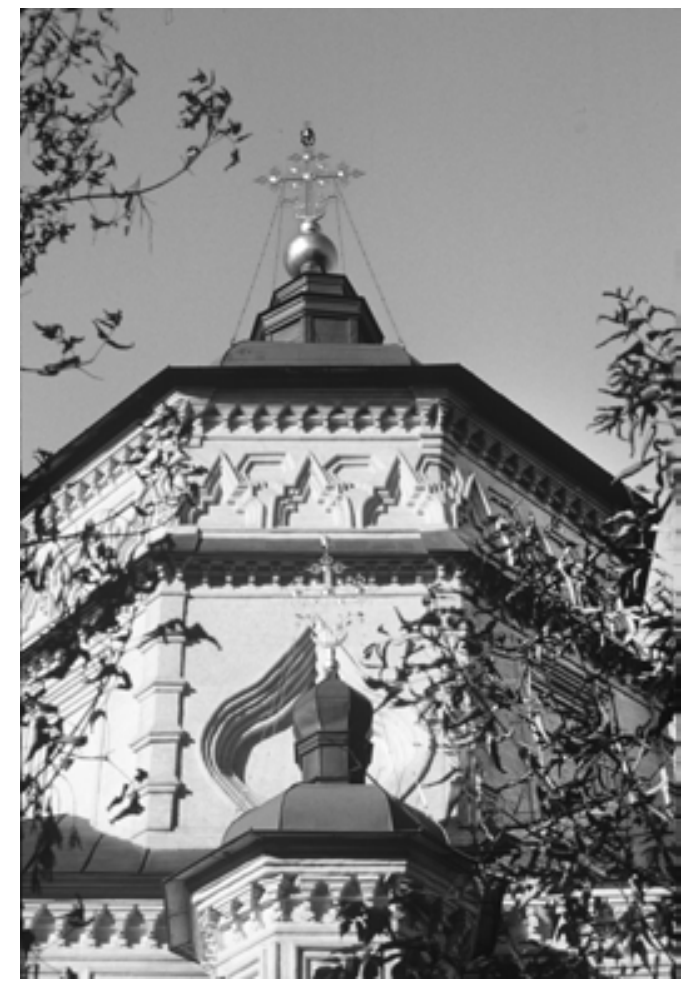

Fig. 15. Irkutsk. Church of the Trinity, east facade

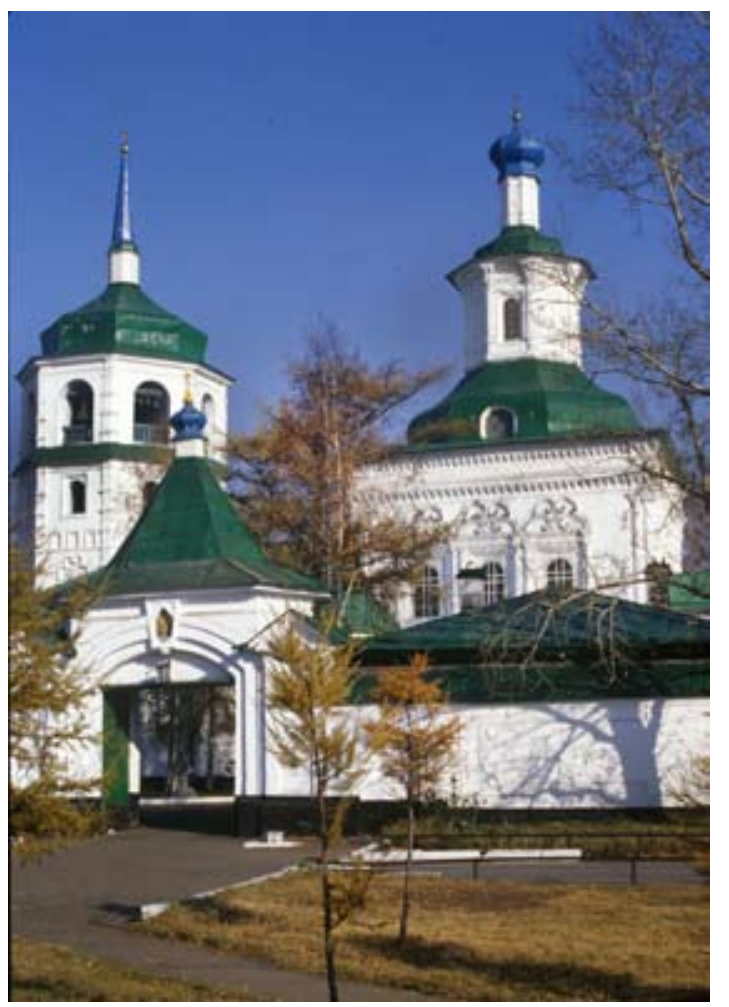

Fig. 16. Irkutsk. Znamenskii Monastery, Cathedral of the Icon of the Sign, south view 


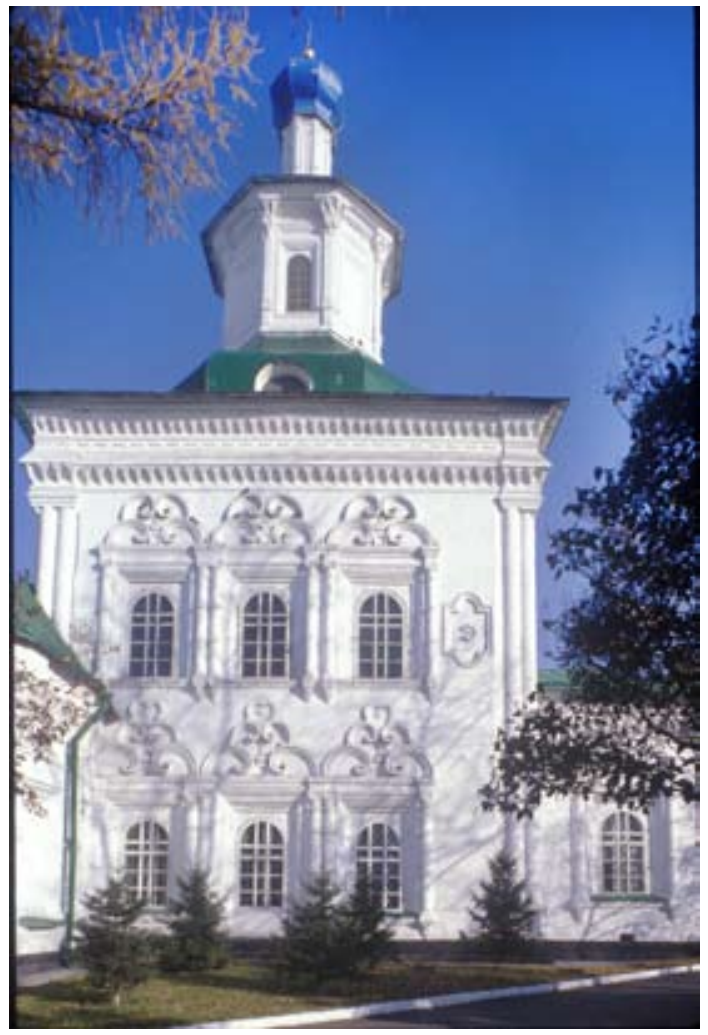

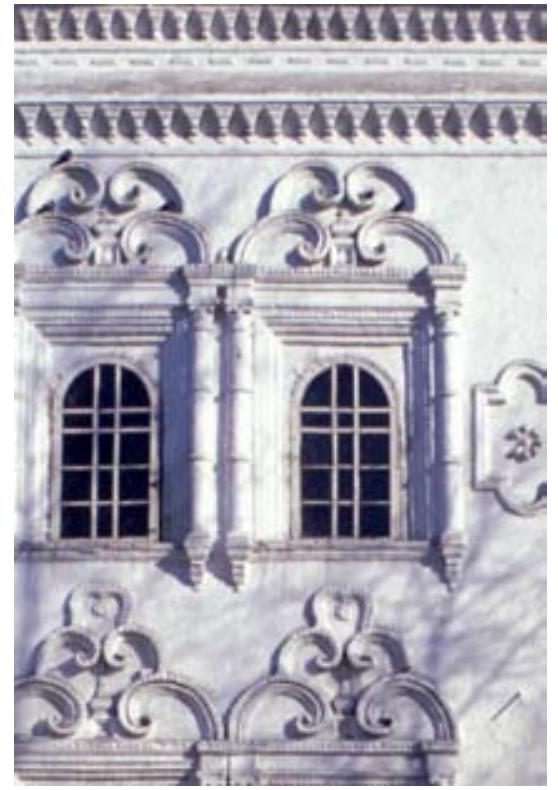

b

Fig. 17. Irkutsk. Znamenskii Monastery, Cathedral of the Icon of the Sign, south facade (a), window surrounds (b)

motif reminiscent of facade ornaments of the Church of the Elevation of the Cross.

During the 1770s Irkutsk church architecture continued a tendency toward greater standardization, exemplified by two very similar structures: the Church of the Archangel Michael and the Church of the Miraculous Icon of the Savior at Urik, a large village some 18 kilometers to the north of Irkutsk. The Archangel Church (also known as the Church of Saint Kharlampii) was begun in 1777 with a grant of 15,000 rubles from the merchant Vasilii Balakshin ${ }^{33}$. Although the structure was defaced in the 1930s by the dismantling of the bell tower and the cupolas, its low-relief facade decoration has been largely preserved. Here as well, eastern motifs appear above the upper windows in decorative elements that resemble the festive headdresses of the region's indigenous peoples (Fig. 18), but also suggests the stupa form ${ }^{34}$.

The lower facade of the church is decorated with brick cartouches that bear a resemblance to decorative figures on the façades of late eighteenth-century churches in the northern town of Totma $^{35}$ (Fig. 19). Nonetheless, there are substantial differences in articulation and implementation. Furthermore, the Totma churches lack the more elaborate façade elements--for example, the complex portals--present in Siberian churches in the Enisei River basin (at Irkutsk, Posolskoe, and Eniseisk, for example). Architects and builders working for local patrons such as Irkutsk merchants would logically have drawn upon regional sources for façade ornamentation, 


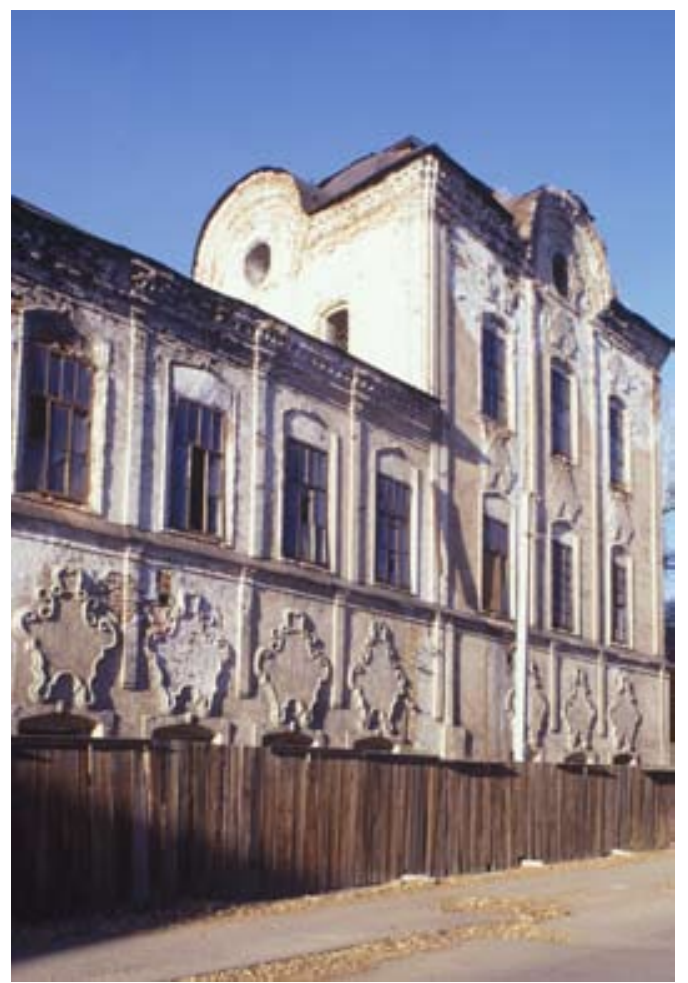

Fig. 18. Irkutsk. Church of St. Kharlampii (Archangel Michael), south facade

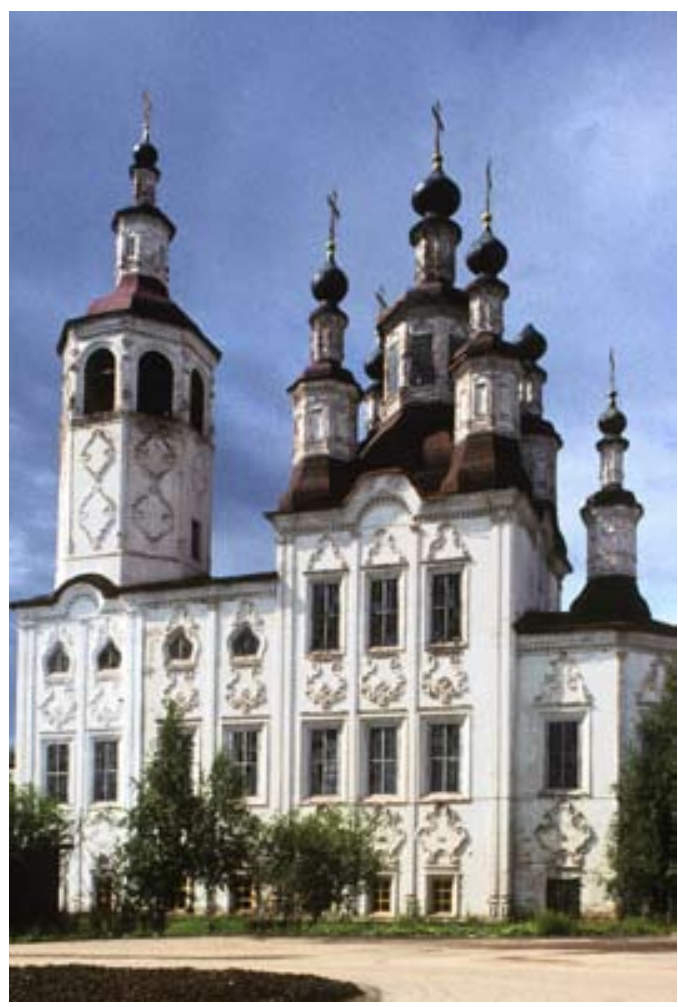

Fig. 19. Totma. Church of the Entry into Jerusalem, south facade 


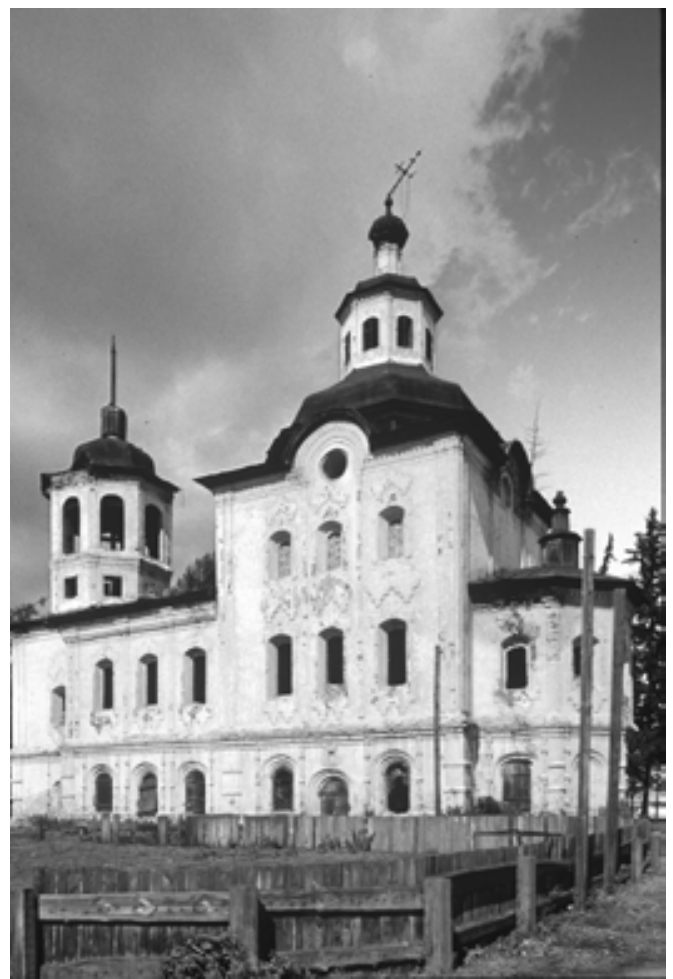

Fig. 20. Urik. Church of the Miraculous Image of the Savior (Nerukotvornyi Spas), southeast view

particularly in the latter half of the eighteenth century. In western Siberia, by contrast, major Tobolsk churches of that period show a more typical Baroque style in façade ornamentation.

Elsewhere in the Irkutsk region, the Savior Church at Urik is less grand in its proportions and detailing than the Church of Archangel Michael, but its general resemblance to the Archangel Church is so close as to suggest a single source for the design (Fig. 20). Indeed, the Savior Church was begun in the summer of 1775 and can be seen as a prototype for the larger church in Irkutsk. The lower (winter) altar of the Savior Church was consecrated in 1779 , while the upper altar (for summer use) was apparently consecrated only in 1796 . The decorative motifs on the north and south facades are particularly close to those of the Irkutsk church, with the same mixture of baroque and eastern patterns. It should be noted that the village itself, located at the confluence of the Urik and Kuda Rivers, is associated with the exile of a number of the Decembrists $^{36}$.

A final example of possible eastern motifs on the facades of churches in the Irkutsk region is the Church of the Purification in the village and ostrog of Belsk, on the Belaia River. Completed after 1788 , this now roofless church is simple in form (only one story), but has bold decorative panels above the main windows (Fig. 21). Although simple in design, the form of these panels was likely derived from similar elements (the stupa outline) on the façades of Irkutsk churches ${ }^{37}$.

Beyond Lake Baikal, Russia's engagement with indigenous cultures--particularly the Buriats--assumes a greater variety of forms. The initial development of Russian settlements in the area to the south and east of Lake Baikal (known as Transbaikal or, more broadly, Dauriia) began in the middle of the seventeenth century. 


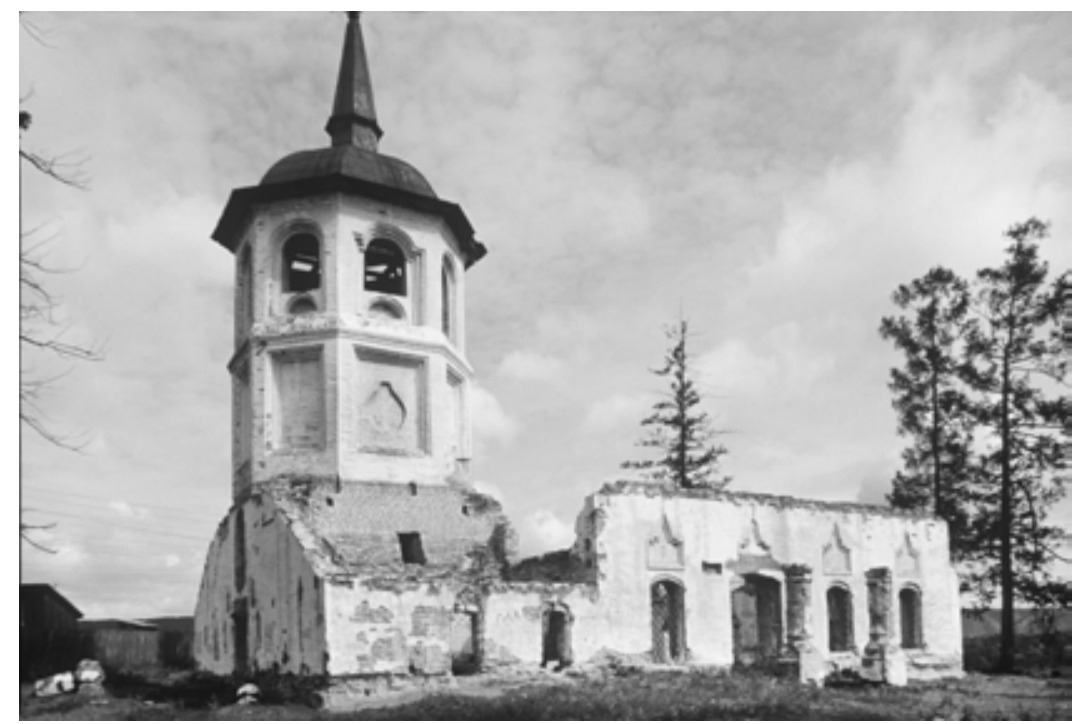

Fig. 21. Belsk. Church of the Purification, south view

In this initial state Cossacks and sluzhilye liudi explored new trading routes to the China and, more immediately, sought tribute in the form of furs (particularly sable) from local populations such as the Buriats and the Tungus. The earliest Russian fort (ostrog) in this great territory was founded in 1648 on an arm of the Barguzin River, some forty kilometers from the eastern shore of Lake Baikal.

However, the direction of Russian settlement in western Transbaikal soon shifted to the south, along the more convenient Selenga River. The Selenga, originating in Mongolia and the main river emptying into the eastern shore of Lake Baikal, served from the seventeenth to the nineteenth centuries as a major conduit for trade and settlement to the east. It became clear that the primary strategic location on the Selenga was its confluence with the Uda River, and at that site, on a bluff above the merging rivers, the fort of Udinsk was established in October 1665 as a wintering outpost ${ }^{38}$.

During the final decades of the seventeenth century, the importance of the Udinsk settlement as a grain distribution point increased, as did the size of the fort, despite the nominal superiority of the Selenginsk fort (see below), located closer to the Chinese border. The Treaty of Nerchinsk, concluded between Russia and China in 1689, required Russian withdrawal from large areas along the Amur River, but led to increased stability for the remaining Russian settlements such as Udinsk, which benefitted not only from trade but also high-level diplomatic travel to China $^{39}$. The settlement's first church, dedicated to the Most Merciful Savior, was built of logs in 1696.

The growing importance of Verkneudinsk ("Upper Udinsk"), as it was became known in the eighteenth century, derived equally from its role as the administrative center of the western Transbaikal region and from its position on one of the most important oriental trade routes, from Irkutsk to the towns of Kiakhtinskaia Sloboda and Troitskosavsk on the Mongolian border. By 1780 the town had two annual trade fairs, in late winter and midsummer. Like other Russian provincial towns during the reign of Catherine the Great, Verkhneudinsk was provided with a highly ordered city grid plan, approved in $1793^{40}$. 


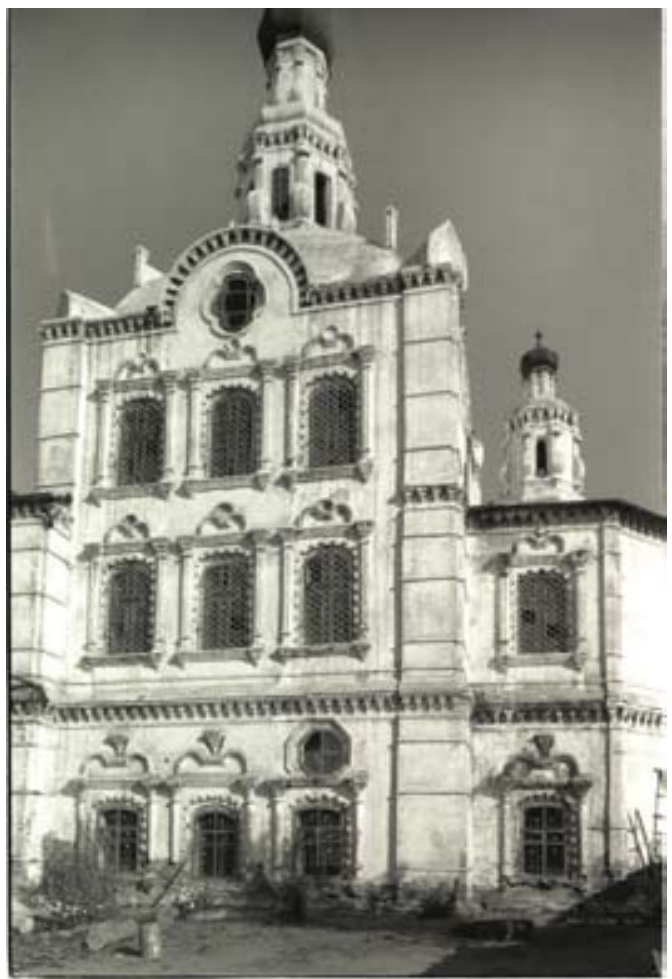

Fig. 22. Ulan-Ude. Cathedral of the Hodegetria Icon of the Mother of God, south facade

Although the plan was modified in 1839, many of its features remain to this day.

The growing economic activity of Verkhneudinsk ultimately enabled the completion of the town's first masonry church, the Cathedral of the Hodigitria Icon of the Mother of God (Fig. 22), begun in 1741 at the site of a log church of the same name, built at the beginning of the eighteenth century. In a pattern typical of brick church construction, from the Russian north to Solikamsk to Eniseisk and Irkutsk, the structure was constructed in two stages. The lower church (for use in the winter) was completed in 1770 , with an altar dedicated to the Epiphany. The upper church, with the main altar, was consecrated only in $1785^{41}$.

Not surprisingly, the basic design and the exterior detail of the Cathedral of the Hodigitria Icon suggest connections with earlier churches

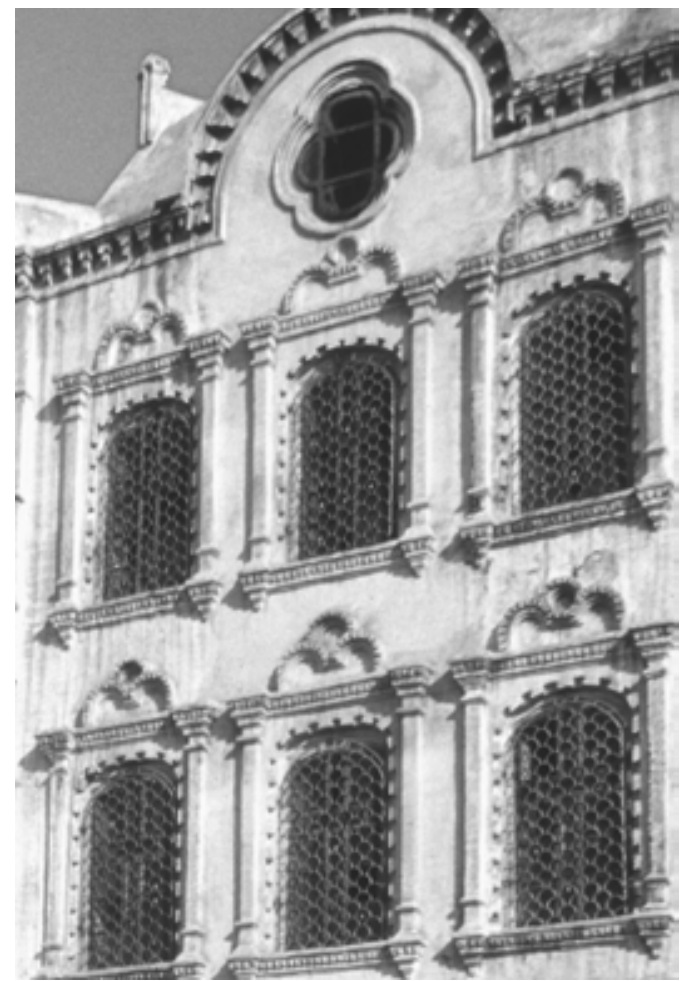

Fig. 23. Ulan-Ude. Cathedral of the Hodegetria Icon of the Mother of God, south facade, window surrounds

in the Irkutsk area, such as the Church of the Miraculous Icon of the Savior in Irkutsk and, more closely, the Church of the Miraculous Icon of the Savior at Urik and the Church of Archangel Michael (Saint Kharlampii) in Irkutsk--all clear examples of the "Siberian baroque"42. The cathedral's double arched pediments over the windows and the articulated window surrounds (Fig. 23) are characteristic of eighteenth-century church design from the Urals eastward, including the Eniseisk area. Additional baroque features include the volutes bracing the drums beneath the main and altar cupolas, as well as the oval windows at the roofline.

Eastern elements, however, are more clearly visible in another example of late eighteenthcentury Orthodox architecture in Buriatiia: the cathedral of the Transfiguration Monastery, located in the village of Posolskoe on the 
eastern shore of Lake Baikal. The origins of the monastery were complicated by disputes with the nearby Trinity-Selenginsk Monastery, whose monks were given the land and fishing rights along that section of Lake Baikal as part of their holdings. By the end of the seventeenth century the treasurer of the monastery, Makarii, had built a small chapel to commemorate the site of the murder in 1661 of Erofei Zabolotskii, the tsar's emissary to Mongolia, whose party was attacked by local Buriats ${ }^{43}$. From that time the site was called "Posolskoe".

However, Metropolitan Ignatii of Siberia and Tobolsk decided to expand the memorial and in 1700 issued a charter stipulating the addition of an altar to the chapel, thus creating a full church dedicated to the Icon of the Virgin of the Sign. The maintenance of this church led to the establishment of a separate monastic institution, supported by two edicts (in 1707 and 1713) from Peter I over the opposition of the Trinity Monastery, which saw its holdings suddenly lessened by the division ${ }^{44}$. During this period the new monastery at Posolskoe had the active support of Grigorii Oskolkov, a prominent merchant associated with the trading center at Kiakhtinskaia Sloboda ${ }^{45}$. Oskolkov, who was buried at the monastery in 1714 , had provided substantial contributions toward construction of the monastery's main church (sobor), dedicated to the Transfiguration of the Savior. This support included the preparation of some 300,000 bricks and other building materials, but the project for a brick church was halted when Peter I banned all masonry construction outside his new capital, Saint Petersburg ${ }^{46}$. Instead, the Transfiguration Church was built of logs and dedicated in 1722 .

Paradoxically, the fate of the Transfiguration Monastery improved after a fire in 1769 that destroyed both its wooden churches, as well as part of the monastic housing. Despite a downgrading of the monastery's status during the reign of Catherine the Great, the means were found to revive the project for a brick church, particularly since the bricks gathered by Oskolkov some sixty years earlier were still at hand. Work on the Church of the Transfiguration (Fig. 24) began in 1773 and concluded in 1778, perhaps with the

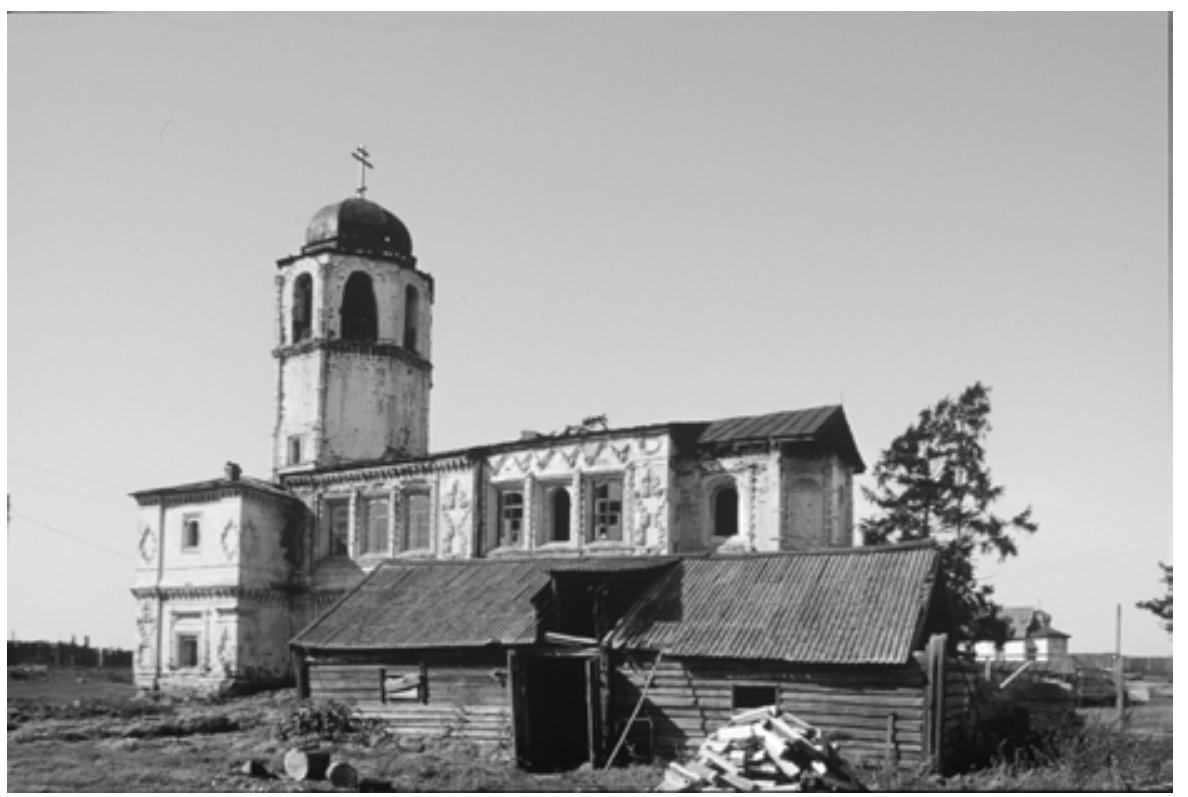

Fig. 24. Posolskoe. Transfiguration Monastery, Cathedral of the Transfiguration of the Savior, southeast view 


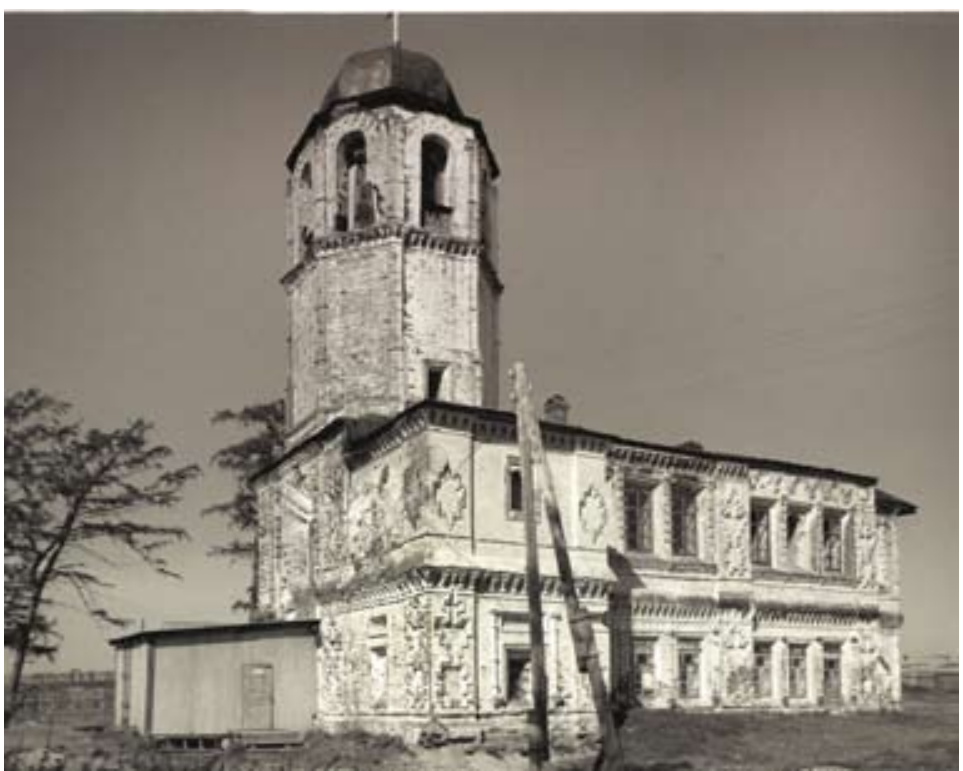

Fig. 25. Posolskoe. Transfiguration Monastery, Cathedral of the Transfiguration of the Savior, southwest view

help of masons from Irkutsk, accessible through a relatively direct crossing of Lake Baikal.

In its plan the Transfiguration Church reflects a typical Siberian composition containing a ground level church (dedicated to the Icon of the Sign) for use in the winter and an upper church with the main altar and two levels of windows. From apse to main structure to refectory and bell tower, the arrangement of components and their proportions resembles that of the Hodigitria Cathedral in Verkhneudinsk. The facade ornamentation, however, is of a different order (Fig. 25). Unfortunately, the Transfiguration Church was severely damaged during the Soviet era, when the domes over both the main structure and the apse, in addition to the entire upper part of the main structure, were dismantled. Nonetheless, enough remains of the facades to reveal the intricacy of the church's ornamental brickwork (Fig. 26). Even the Hodigitria Cathedral falls short of this level of embellishment, despite the general similarity of outline between the two churches.
The deeply-profiled windows of the Transfiguration Church, with terra cotta pilasters and linked scroll pediments above the second level, are complimented by a robust, if naive, dentilation that separates the two levels of the structure. Similar motifs are present in other Enisei River basin churches, specifically in Eniseisk itself. Other facade motifs suggest comparison with contemporary church architecture in Irkutsk. For example, the intricate terra cotta relief figures on the corners of each of the structural components of the Transfiguration Church remind of the stylized humanoid figures on the corners of the Church of the Elevation of the Cross.

The most remarkable feature of the Transfiguration Church is its elevated west portal (Fig. 27), with an elaborate profiled frame (Fig. 28). Decorative molded brick is placed in complex, layered patterns with ogival points that emphasize the presence of a shrine. Here one sees direct comparisons with such monuments in Eniseisk as the Church of the Trinity (Fig. 29), begun in 1772, completed on the exterior in 1776 , and on the interior in 


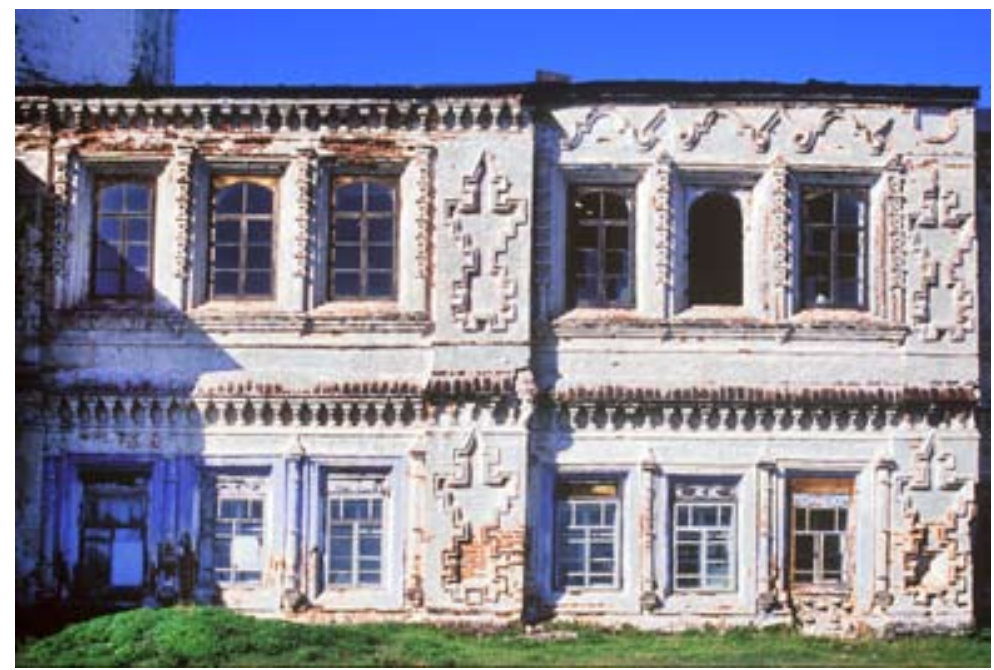

Fig. 26. Posolskoe. Transfiguration Monastery, Cathedral of the Transfiguration of the Savior, south facade

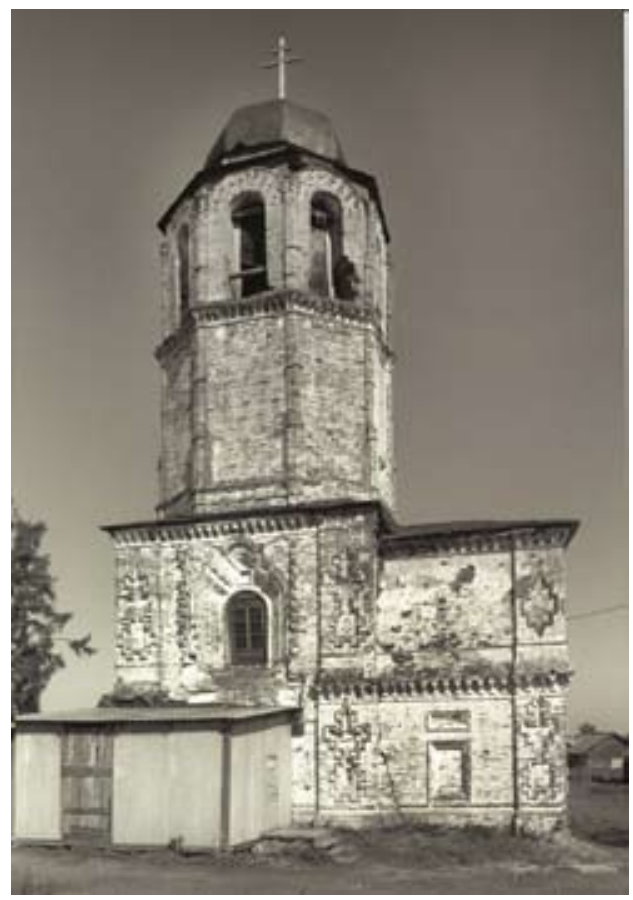

Fig. 27. Posolskoe. Transfiguration Monastery, Cathedral of the Transfiguration of the Savior, west facade with bell tower

the $1780 \mathrm{~s}^{47}$. Containing elements of church design from the Vologda territory and the Urals (Solikamsk), the Trinity Church also displays features peculiar to Siberia, both western and eastern. Although this remarkably beautiful church was largely dismantled during the Soviet period and the remainder used as a shed and barn, the extant structure has a deeply profiled ornamental west portal (Fig. 30) as well as distinctive window surrounds with tower 


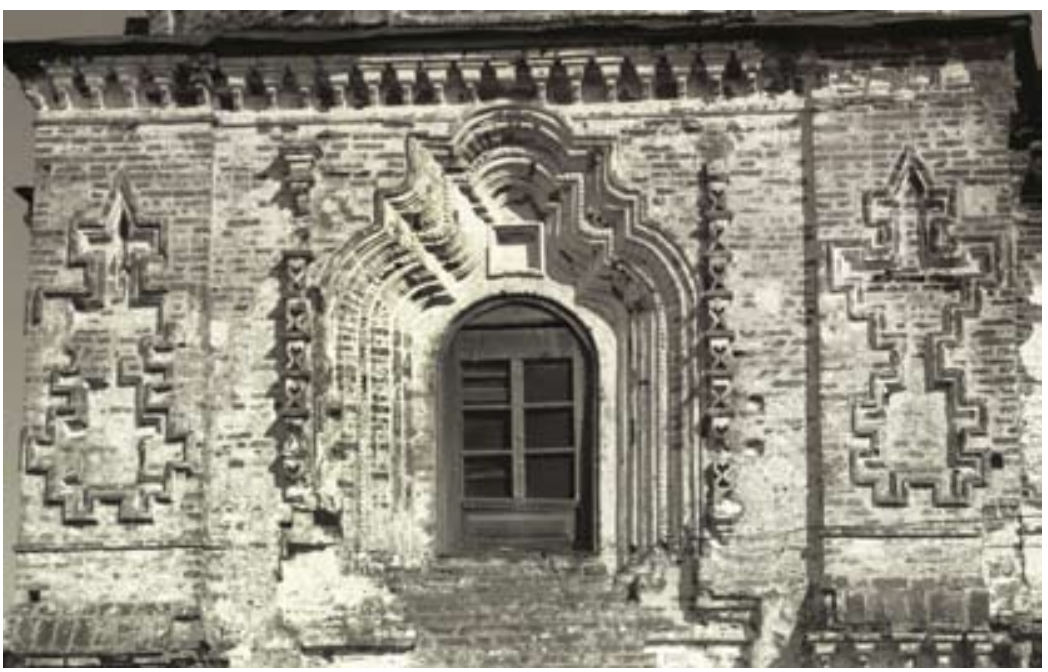

Fig. 28. Posolskoe. Transfiguration Monastery, Cathedral of the Transfiguration of the Savior, west facade, main portal with perspective arch

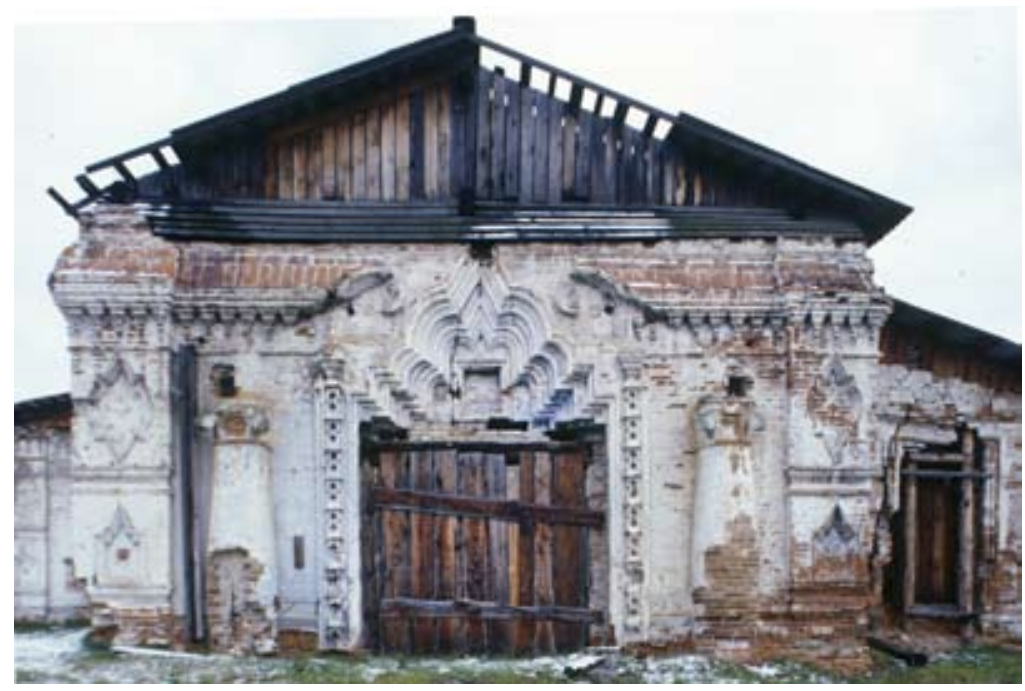

Fig. 29. Eniseisk. Church of the Trinity, west facade, main portal with perspective arch

pediments that suggest the possible influence of Asian motifs (Fig. 31).

Whatever the similarities between the west portal at Posolskoe and the surviving fragments of the west facade of the Eniseisk Trinity Church, the Posolskoe church displays a more flamboyant use of this framing technique, culminating over the door in a burst of space defined by a curved pediment. This complex form of outlining in depth also appears in the windows of the main structure of the Church of the Elevation of the Cross in Irkutsk. The north and south portals of the Irkutsk church, however, show a different resolution--remarkable in its own way--conveyed through the use of elaborate terra cotta ornament. Furthermore, the original west portal of the Irkutsk church was obscured by later rebuilding and extensions. 


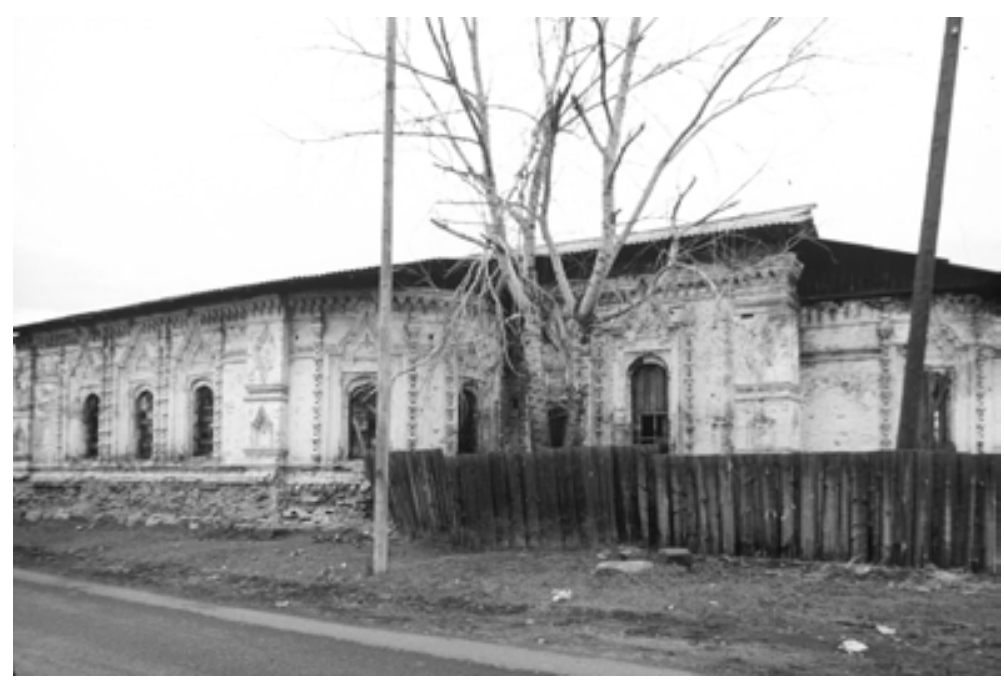

Fig. 30. Eniseisk. Church of the Trinity, southeast view

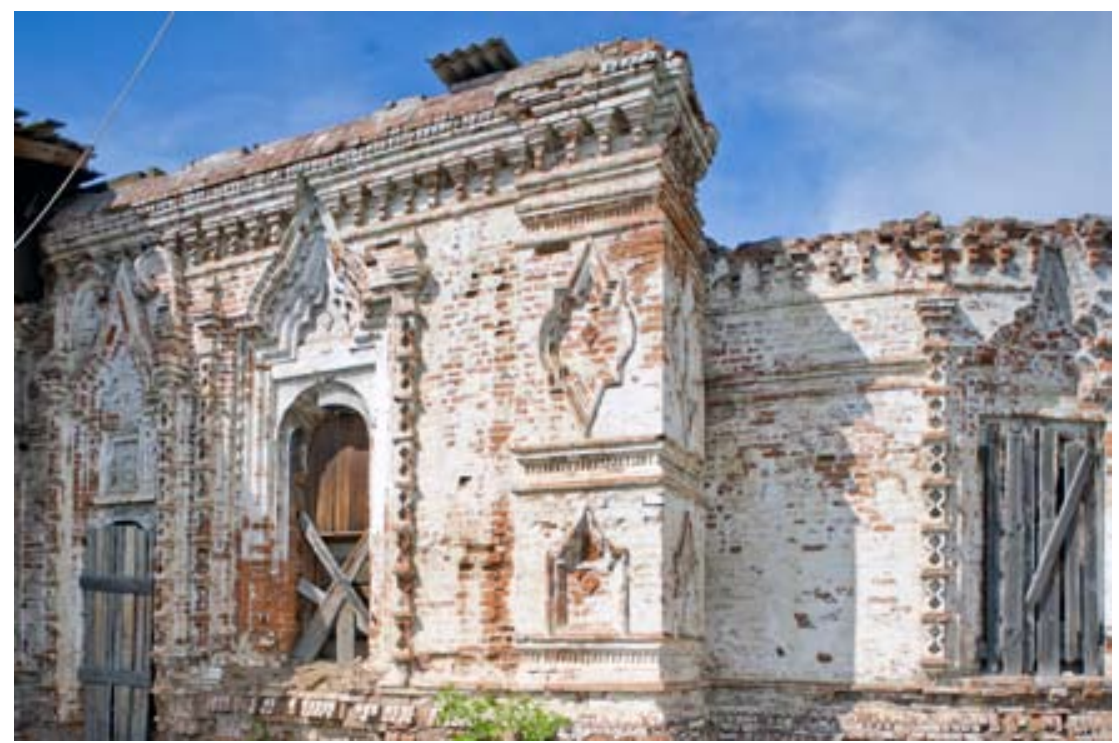

Fig. 31. Eniseisk. Church of the Trinity, south facade (under restoration), east corner, window surrounds and ornamental motifs

Thus the portal of the Transfiguration Church at Posolskoe represents a highly unusual form by virtue of its state of preservation and the degree of its decorative elaboration. The impression created by the ensemble of the west facade--portal, profiled frame, and relief figures on each corner--is far from typical in Orthodox architecture. Indeed, the extraordinary, archaic force of the design is unsettling, as though creating the entry to a temple of some obscure rite. As with the related forms and ornamental motifs on the facades of other churches in the Enisei River basin, there exists the possibility of oriental derivation at Posolskoe, even though the Transfiguration Church lacks obvious Buddhist references such as the Dharma wheels at the 
Church of the Elevation of the Cross. Indeed, Buddhism, in its Indo-Tibetan variant, is not the only possible source for the ornamentation, particularly in view of the artistry of Buriat, or even Yakut, culture.

The question of architectural derivation at Posolskoe remains a matter for speculation. One specialist has stated unequivocally that the Transfiguration Church and the Church of the Elevation of the Cross were built by the same architect: "A close study of the architecture of [the Church of the Transfiguration] enables one to confirm that it was built by the architect of the Church of the Elevation of the Cross. In the architecture of the Church of the Transfiguration of the Savior, the motifs that had been developed in the amazing Irkutsk temple are not only repeated, they are reworked in a new way, and-the main thing--they are applied with a convincing economy and logic" ${ }^{\circ 4}$.

Yet in purely formal terms the west, main facade of the Posolskoe church is closer to that of the Trinity Church in Eniseisk. Is it possible that the same master (or masters) was involved in the construction of all three churches: Irkutsk, Eniseisk, Posolskoe? And how well did the master (or masters) know the patterns of Asian ornament? Certainly the Enisei-Angara-Baikal waterway provided a ready conduit for ideas, people, and materials, while the Selenga River continued the path toward Mongolia and China. But in the absence of documentary evidence this position remains hypothetical, as does the possibility of ornamental influence from Buddhist or other indigenous Asian sources. It is, nonetheless, reasonable to assume such influence, particularly in view of the primary mission of the Transfiguration Monastery: to propagate the Orthodox faith among the Buriats. In this regard the entrance to the Transfiguration Church would have projected a striking image of Orthodoxy in Asia $^{49}$.
One of the latest eighteenth-century examples of Asian motifs in facade ornamentation occurs at the Church of the Intercession in Krasnoiarsk, the oldest extant monument in the city. Begun in 1785 , the church had two side altars that were completed in 1790 , but the main altar was not consecrated until $1795^{50}$. The main structure of the church consists of a high central space culminating in an extended drum and cupola (Fig. 32). But the exterior facade, painted red with white detail, is defined on the lower level by large distinctive ornamental motifs that again suggest Asian origins--both the stupa and lotus forms (Fig. 33) $)^{51}$.

The exuberance of late nineteenth-century eclectic architecture in Irkutsk is perhaps best illustrated in the boldly polychromatic Church of the Kazan Icon of the Mother of God (not to be confused with the destroyed Irkutsk main cathedral of the same dedication). Endowed by the merchant Alexander Sibiriakov and built in 1885-92, the Kazan church reflects a florid variant of the Russo-Byzantine style common in the late

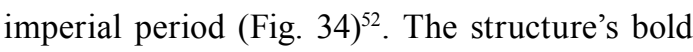
orange walls, deeply articulated and surmounted by a panoply of blue and white checked cupolas, suggest something closer to the British Raj in nineteenth-century India than to typical Russian church design of the same period. The colors of the walls remind of the red sandstone work applied in the so-called Indo-Saracenic style, which also frequently displayed a multitude of polychrome domes ${ }^{53}$. The comparison is all the more appropriate when considering the proximity of Irkutsk to Asia. As a competing imperial power in Asia, Russia was certainly aware of the British manner of imperial rule in India and the uses of architecture in that style. And whatever the identity of the Kazan Church architect (probably trained in or a resident of Saint Petersburg), he could have seen published illustrations of British imperial architecture in India. Indeed, the increased scale 


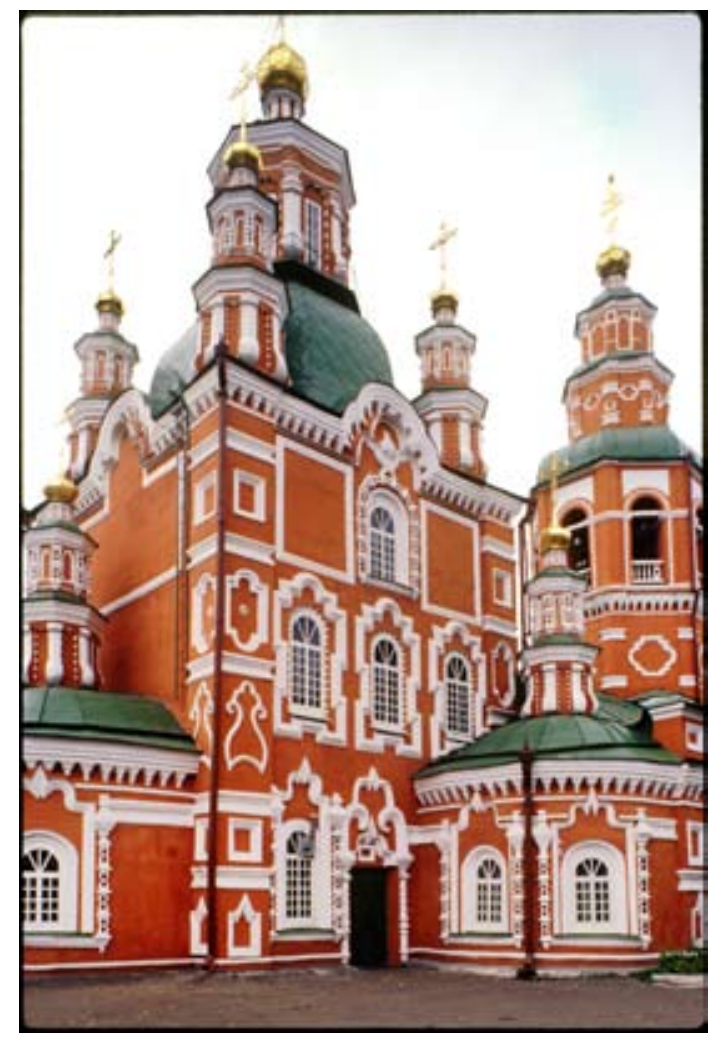

Fig. 32. Krasnoiarsk. Cathedral of the Intercession of the Mother of God, northeast view

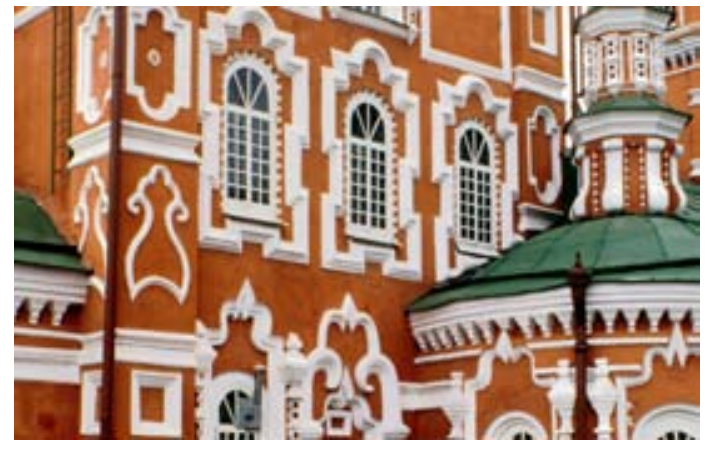

Fig. 33. Krasnoiarsk. Cathedral of the Intercession of the Mother of God, north facade, window surrounds and ornamental motifs

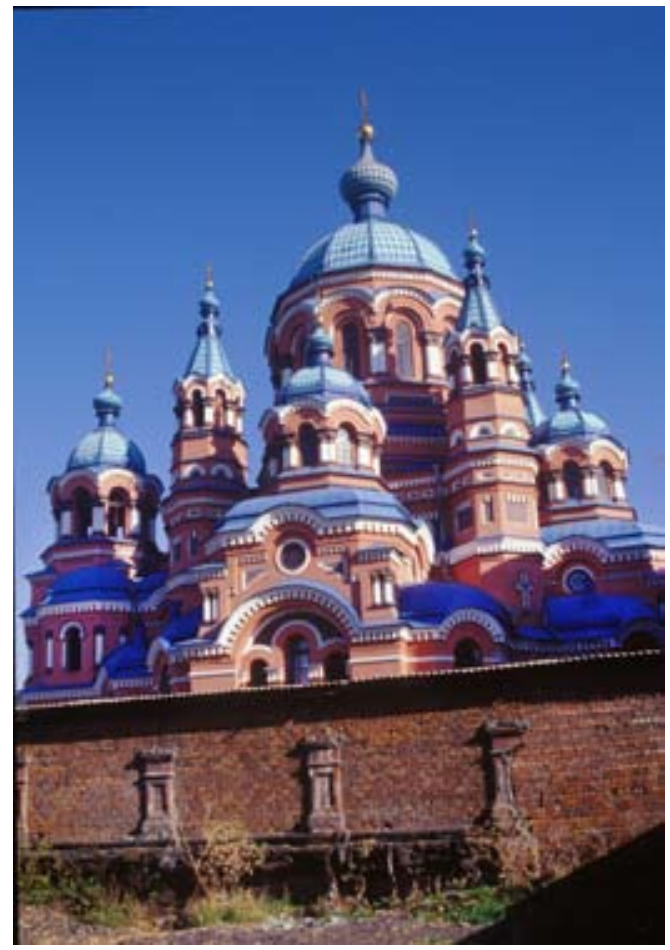

Fig. 34. Irkutsk. Church of the Kazan Icon of the Mother of God, south view 


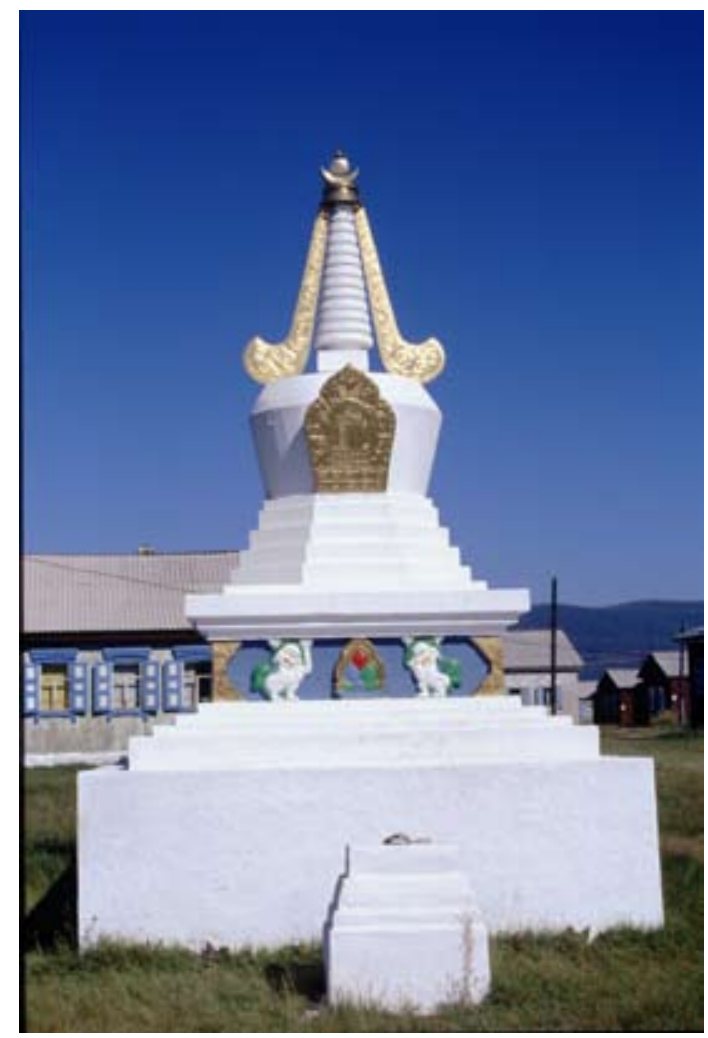

Fig. 35. Ivolginsk datsan. Stupa
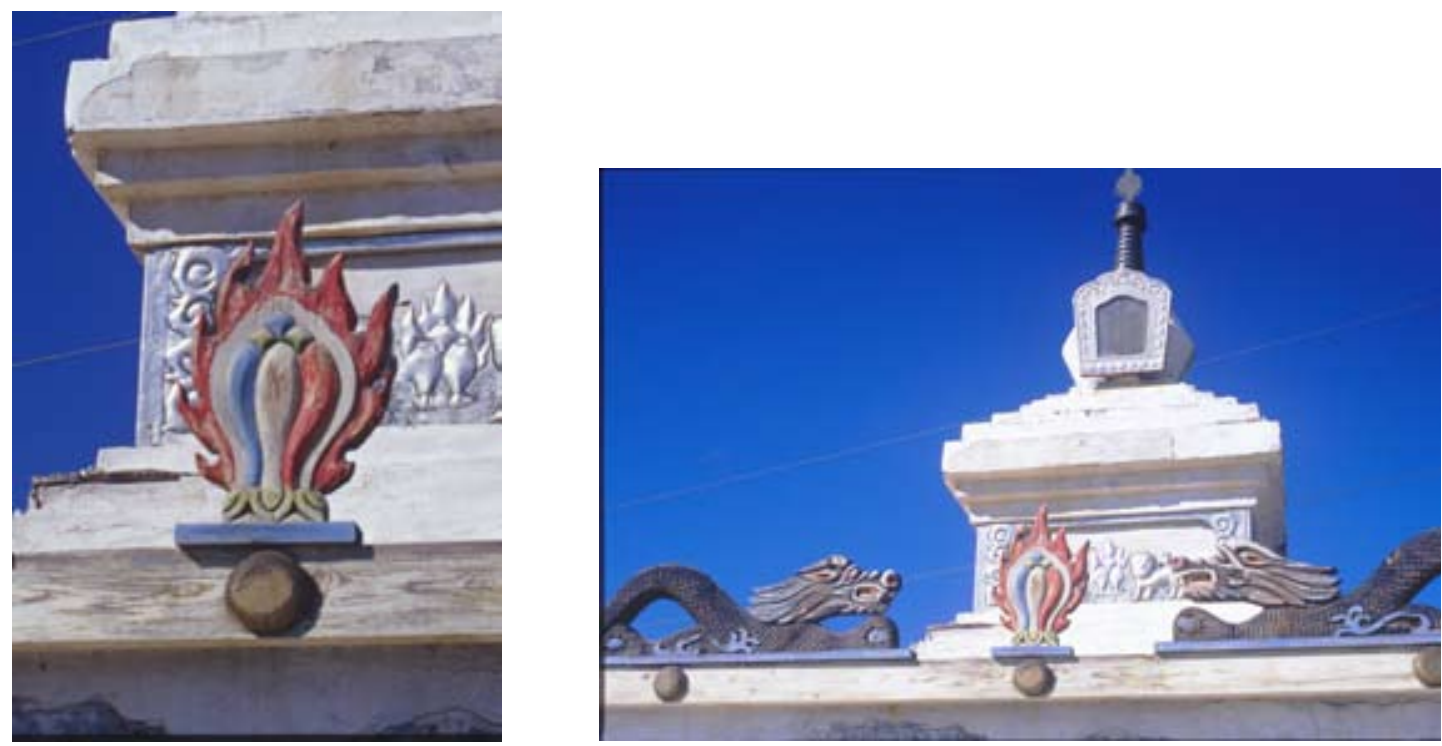

Fig. 36. Gusinoozersk. Tamchinskii datsan, shrine (suburgan) with flaming ornamental figure (a), upper tier of suburgan (b) 

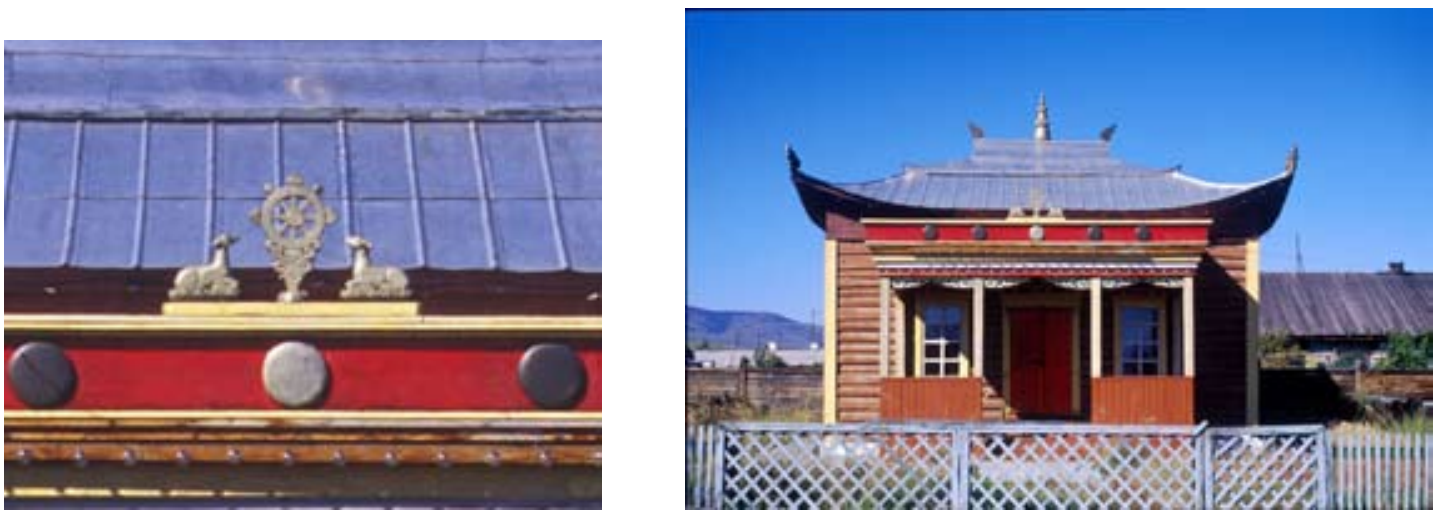

Fig. 37. Gusinoozersk. Tamchinskii datsan, wooden temple (Dugan Aiusha), pediment with figure of Dharma wheel (Eightfold Path) (a), Gusinoozersk. Tamchinskii datsan, wooden temple (Dugan Aiusha) (b)

of church construction in Siberia, even before the Trans-Siberian Railway, represents a similar use of imposing, symbol-laden architectural forms as a way of establishing state presence over a large territory in Asia.

The preceding survey of ornamental forms on the facades of Siberian churches (primarily eighteenth-century) demonstrates the probable Asian origins of certain of the most visible motifs. In particular, the traditional ascending form of the stupa, with a pointed, ogival shape resembles both the designs of window pediments and facade ornamentation between church windows. It can be assumed that these motifs express no Buddhist content, but reflect a circulation of ornamental motifs arising from extensive mercantile contacts between Siberian cities (particularly those near the Mongolian border) and China. The formal origins, however, appear to be not Chinese temple architecture, but Mongolo-Tibetan architecture, which reflects Indian devotional forms. These questions deserve further study not only in the interests of a broader awareness of relations between Russia and other Asian cultures but also for a deeper understanding of the Eurasian component of Russian identity.

For a discussion in English of the Naryshkin Baroque and late seventeenth-century ornamentalism, see William Craft Brumfield, A History of Russian Architecture (Cambridge: Cambridge University Press, 1993), 184-93. On the development and meaning of the stupa as an architectural manifestation of the Buddha, see Benjamin Rowland, The Art and Architecture of India (Harmondsworth: Penguin Books, 1953), 51-54; and Debala Mitra, Buddhist Monuments (Calcutta: Sahitya Samsad, 1969), 21-30. Chinese Buddhist architecture developed the vertical form as pagoda, but the influence of the Indian stupa is also evident. See Laurence Sickman and Alexander Soper, The Art and Architecture of China (Harmondsworth: Penguin Books, 1971), 389-92, 402, 405-07.

2 A detailed iconographic and formal analysis of Hindu and Buddhist devotional lamps is presented in Sean Anderson, Flames of Devotion: Oil Lamps from South and Southeast Asia and the Himalayas (Los Angeles: UCLA Fowler Museum of Cultural History, 2006).

3 On the eighteenth century architecture of Tobolsk and Tiumen, and the influence of Urkrainian prelates such as Bishop Filofei Leshchinskii, see William C. Brumfield, "Photographic Documentation of Architectural Monuments in Siberia: Tiumen Province," Visual Resources, 16 (2000)4:311-33.

4 The importance of the Savior Church as a key monument in the so-called "Tobolsk baroque" is discussed in S. P. Zavarikhin, V drevnem tsentre Sibiri (Moscow: Iskusstvo, 1987),136-37; and S. P. Zavarikhin and V. V. Kniazhev, Ekologiia zodchestva (St. Petersburg: Stroiizdat, 1995), 152-53. During the Soviet era the entire upper story of the church was demolished, with all cupola structures, thus leaving only the first floor.

5 The possibility of a connection with the non-Christian architecture of East Asia is also suggested in V. V. Kirillov, Tobol'sk (Moscow: Iskusstvo, 1984), 103. Although not directly related to the question of derivation, the views of Anatolii Kulomzin, a high Tsarist official responsible for the settlement of Siberia in the early twentieth century, are telling. On an 
inspection trip to the Transbaikal region in 1897 , he noticed the disparity between the attractive Buddhist temples of the Buriats and the crude forms of hastily-built Russian log churches. This observation suggests that Russians had long taken note of the design of Budddhist temples in Asia. See Steven Marks, "Conquering the Great East," in Stephen Kotkin and David Wolff., eds., Rediscovering Russia in Asia: Siberia and the Russian Far East (Armonk, N. Y.: M. E. Sharpe, 1995), 33-34.

6 The date of the founding of Irkutsk is discussed in A.N. Kopylov, “O date osnovaniia Irkutska,” Istoriia SSSR,” (1960)5:16566. See also Dmitrii Rezun, "Po povodu daty osnovaniia Irkutska,” Zemlia Irkutskaia, 1 (1994):4-5.

7 For a general description of the tea trade with China, see Nina Edinarkhova, "O chae i chainoi torgovle," Zemlia Irkutskaia, 5 (1996):17-18. See also Vadim Shakherov, "Reformator iz Irkutska (Zhizn' i vzgliady irkutskogo kuptsa Fedora Shchegorina)," Zemlia Irkutskaia, 1 (1994):9-14.

8 A comprehensive survey of all the churches, extant and destroyed, in the Irkutsk eparchy is contained in Irina Kalinina, Pravoslavnye khramy Irkutskoi eparkhii (Moscow: Galart, 2000). After Tiumen and Tobolsk, Irkutsk became in 1700 the third Siberian city capable of producing bricks on a large scale. See Nadezhda Polunina, $U$ istokov kamennogo grada (Irkutsk: VSKI, 1979), 14.

9 On the northern origins of Irkutsk settlers and the consequent influence on local church construction, see B. I. Ogly, “Arkhitekturnye pamiatniki Irkutska XVIII-nachala XIX vv.," Arkhitekturnoe nasledstvo, 27 (1979):161-62. More detailed information is provided in I. I. Serebrennikov, O starinnikh domakh i tserkvakh $v$ Irkutskoi gubernii (Irkutsk, 1915).

10 For an analysis on the role of churches in the Irkutsk cityscape, see A. V. Korzun, "Osobennosti kul'tovoi arkhitektury Irkutska," in A. V. Dulov, ed., Pamiatniki istorii i kul'tury Irkutska (Irkutsk: VSKI, 1993), 370-76. See also Ogly, "Arkhitekturnye pamiatniki," 168.

11 On the career of Dolgikh in Siberia, see Nadezhda Polunina, Zhivaia starina Priangar'ia (Moscow: Iskusstvo, 1990), $27-$ 28.

12 S. V. Kopylova, Kamennoe stroitel'stvo v Sibiri. Konets XVII-XVIII vv. (Novosibirsk,1979), 182-83.

13 The Irkutsk vicariate was sanctioned in 1706, but the church in Irkutsk remained subordinate to the metropolitanate in Tobolsk. The autonomous eparchy of Irkutsk and Nerchinsk was not established until 1727. See Tat'iana Romantseva, "Dukhovnyi vertograd Sibiri," Zemlia Irkutskaia,14 (2000):6-7.

14 The dedications of the other altars in the Savior Church are provided in Kalinina, Pravoslavnye khramy, 140-41.

15 On the new Savior Church frescoes, see Polunina, U istokov, 76-80.

16 The Church of Saint Dmitrii is described in Genrikh Bocharov and Vsevolod Vygolov, Sol'vychegodsk. Velikii Ustiug. Tot'ma (Moscow: Iskusstvo, 1983), 244-46. See also William Brumfield, "Velikii Ustiug: Vzgliad cherez ob"ektiv amerikanskogo uchenogo-fotografa," in Velikii Ustiug. Kraevedcheskii al'manakh, vol. 2, ed. V. A. Sablin (Vologda: Legiia, 2000), 355, with accompanying plates; and William Brumfield, Sviatyni russkogo severa (Vologda: ARNIKA, 2001), 23.

17 The original log church, dedicated to an icon of the saints brought from Velikii Ustiug, was replaced in the middle of the eighteenth century by a brick structure that was among the most interesting examples of Irkutsk architecture. Despite its official landmark status granted in 1925, the church was closed and destroyed in the 1930s. See Kalinina, Pravoslavnye khramy, 137-39.

18 The growth of merchantry in Irkutsk in surveyed in Vadim Shakherov, "Dlia pol'z soobshchestva dostatok istoshchaia," Zemlia Irkutskaia, 5 (1996):2-10.

19 On the trade fairs, see D. Ia. Rezun and O. N. Besedina, Gorodskie iarmarki Sibiri XVIII-pervoi poloviny XIX v. Iarmarki Vostochnoi Sibiri (Novosibirsk: 1993).

20 Merchant patronage of church construction is discussed in Tamara Kriuchkova, “'...Userdiem i kapitalom'. O metsenatstve pri stroitel'stve Irkutskikh tserkvei,” Zemlia Irkutskaia, 5 (1996):66-75.

21 Ogly, "Arkhitekturnye pamiatniki," 162.

22 The original petition by Shcherbakov led to erroneous attributions of patronage of the church in works such as I. V. Kalinina, "Kul'tovoe pravoslavnoe zodchestvo," in Dulov, Pamiatniki, 382, 384. Kalinina corrects her own error in Pravoslavnye khramy, 113.

23 On the relation of the posadskii Amosov to the construction of the church, see Kriuchkova, “'...Userdiem i kapitalom'," 67.

24 On the remaining of the various altars and the church as a whole in 1867, see Kalinina, Pravoslavnye khramy, 113. The reason most frequently given for the change was the presence of another large Trinity Church in Irkutsk. It should be noted that such changes were not unusual in Russian Orthodox Churches, particularly after a major renovation.

25 The distinctiveness of the decorative detail of the church of the Cross and its relation to the churches of the Russian north and Solikamsk is eloquently stated in Georgii K. Lukomskii, Pamiatniki starinnoi arkhitektury Rossii. Nasha Provintsiia (Petrograd: 1916), 92-93.

26 I. E. Grabar', Istoriia russkogo iskusstva, vol. 2 (Moscow: Knebel, 1909), 143, 146. The influence of Mongol and Chinese architecture in decorative details such as kokoshniki above the windows was noted in D. A. Boldyrev-Kazantsev, Narodnoe iskusstvo Sibiri (Irkutsk, 1924), 7.

27 See Ogly, "Arkhitekturnye pamiatniki," 167.

28 On the "Siberian baroque," see T. S. Proskuriatova, "Osobennosti sibirskogo barokko," Arkhitekturnoe nasledstvo, 27 (1979):147-160. She notes that the term was first defined in Boldyrev-Kazantsev, Narodnoe iskusstvo, 13-14.

29 See comments on the baroque character of the Trinity Church in T. S. Proskuriakova, “O traditsionalizme v monumental'noi arkhitketure Sibiri XVIII v.," Arkhitekturnoe nasledstvo, 34 (1986): 157. See also Kalinina, Pravoslavnye khramy, 144.

30 The history of the Monastery of the Icon of the Sign is surveyed in Natal'ia Torshina, "Znamenskii monastyr'," Zemlia Irkutskaia, 10 (1998):24-27. 
31 This was apparently the third church in Irkutsk constructed with money provided by Bechevin, but he did not live to see its completion. Bechevin was the most prominent victim of the notorious Peter Krylov, a tax inspector sent from Saint Petersburg in 1758, who used threats and violence to extort large sums of money (over 150,000 rubles) from Irkutsk merchants involved primarily in the liquor trade. Bechevin's donations to the church and his death at the hands of Krylov are surveyed in Kriuchkova, "'...Userdiem i kapitalom,", 67-68. The regulation of the liquor trade in Irkutsk, with further references to the Krylov affair, is described in Ol'ga Cherniavskaia, "Iz istorii vinokureniia v Irkutskoi gubernii," Zemlia Irkutskaia, 5(1996):22-24.

32 Kalinina, Pravoslavnye khramy, 100.

33 The beginning of construction of the Archangel Church is dated to May 1779 in Kriuchkova, “'...Userdiem i kapitalom', 70. But other sources give 1777. See Kalinina, Pravoslavnye khramy, 127; and Polunina, Zhivaia starina, 56.

34 This resemblance is noted in Kalinina, Pravoslavnye khramy, 128.

35 On the churches of Totma, see William C. Brumfield, "Photographic Documentation of Architectural Monuments in the Russian North: Vologda Province," Visual Resources, 14 (1998) 1:99-103; and William Brumfield, "Pamiatniki tserkovnoi arkhitektury totemskogo raiona," in Tot'ma. Kraevedcheskii al'manakh, vol. 3, ed. A. V. Kamkin (Vologda: Legiia, 2001), 282-84, and plates 9-14.

36 Connections between the Savior Church and the exiled Decembrists in Urik are noted in Kalinina, Pravoslavnye khramy, 397-98. See also Polunina, Zhivaia starina, 136-40; and Tamara Pertseva, "Pis'ma iz Urika," Zemlia Irkutskaia, 6 (1996):60-65.

37 On the Church of the Purification at Bel'sk, see Kalinina, Pravoslavnye khramy, 189. See also William C. Brumfield, "Photographic Documentation of Architectural Monuments in the Irkustk Region of Eastern Siberia," Visual Resources, 19 (2003) 2:107-147.

38 A detailed study of the Udinsk fort is contained in Aleksei V. Tivanenko, Udinskii ostrog: pervoe stoletie Ulan-Ude (UlanUde: BNTs SO RAN,1995).

39 See Aleksandr R. Artem'ev, Goroda i ostrogi Zabaikal'ia i Priamur'ia vo vtoroi poloviny XVII-XVIII vv. (Vladivostok: DVO RAN, 1999), 72-75. At least two major embassies sent by Peter I (in 1693 and 1719) passed through Udinsk. On the latter see John Bell, A Journey from St. Petersburg to Pekin (1719-22), edited with an introduction by J. L. Stevenson (New York: Barnes and Noble, 1966).

40 The city plans are reproduced in Liudvig K. Minert, Pamiatniki arkhitektury Buriatii (Novosibirsk: Nauka, 1983$), 17$.

${ }_{41}$ Archival sources on the construction history of the Hodigitria Cathedral are presented in Valerii K. Gur'ianov, Po Bol'shoi, Bol'shoi Nikolaevskoi (Ulan-Ude: BNTs SO RAN, 1998), 28-29. See also Ekaterina S. Mitypova, Pravoslavnye khramy v Zabaikal'e (XVII-nach. XXvv). (Ulan-Ude: BGU, 1997), 27-29; and Minert, Pamiatniki, 21-25.

42 References to the cathedral within the broader context of Siberian church architecture are noted in T. S. Proskuriakova, "O traditsionalizme v monumental'noi arkhitketure Sibiri XVIII v.," Arkhitekturnoe nasledstvo, 34 (1986): 119-20.

43 The slaughter of Zabolotskii's group, which included his son, is recorded in Georgii N. Rumiantsev, Sbornik dokumentov po istorii Buriatii XVII v. (Ulan-Ude: 1960), 192. On the commemoration of Zabolotskii, see Mitypova, Pravoslavnye khramy, 17-18.

44 Minert, Pamiatniki,122-23.

45 Mitypova, Pravoslavnye khramy, 18.

46 Minert, Pamiatniki,123.

47 On the Church of the Trinity, see G. L. Ruksha, G. F. Bykonia, N. I. Drozdov, et al., Pamiatniki istorii i kul'tury krasnoiarskogo kraia, vol. 1 (Krasnoiarsk: Krasnoiarskoe knizhnoe izdatel'stsvo, 1989), 99-101; and Boris V. Gnedovskii and Ella D. Dobrovol'skaia, Vverkh po Eniseiu (Moscow: Iskusstvo, 1980), 43-45.

48 Minert, Pamiatniki, 126-27.

49 On the missionary activity of the Transfiguration and Trinity Monasteries, which included the translation of religious texts into Mongolian, see Mitypova, Pravoslavnye khramy, 23. The other surviving brick church at the Transfiguration Monastery was dedicated to Saint Nicholas and built in 1802-1812 to replace a log church assembled after the 1769 fire. This small church had little exterior decoration and was also much disfigured during the Soviet era.

s0 On the construction of the Church of the Intercession in Krasnoiarsk, see V. I. Tsarev and V. I. Krushlinskii, Krasnoiarsk: Istoriia i razvitie gradostroitel'stva (Krasnoiarsk: Klaretianum, 2001), 157.

${ }_{51}$ G. F. Bykonia, Iu. I. Grinberg and K. Iu. Shumov, "Pokrovskaia tserkov' v Karsnoiarske--pamiatnik arkhitektury XVIII veka," in G. L. Ruksha, ed., Pamiatniki istorii i kul'tury krasnoiarskogo kraia (Krasnoiarsk: Krasnoiarskoe knizhnoe izdatel'stvo, 1989), 314-21. The authors refer to the decorative elements on the facade only as "trefoils" (trilistniki).

52 The philanthropic activity of Aleksandr Sibiriakov (including the Kazan Church) is surveyed in Kriuchkova, “'...Userdiem i kapitalom,," 73-4. Despite the large size of the Kazan Church, its authorship has remained unattributed in specialized sources, even though the names of the painters who worked on the iconostasis have been duly recorded. See Kalinina, Pravoslavnye khramy, 120-21.

53 Among many examples, the Lakshmi Vilas Palace, built in Baroda in the 1870s, is of special interest. See Thomas R. Metcalf, An Imperial Vision: Indian Architecture and Britain's Raj (Berkeley: Univ. of California Press, 1989), 112-20. 


\title{
Восточные мотивы в орнаментах сибирской церковной архитектуры XVIII века
}

\author{
У.К. Брумфильд \\ Университет Тулейн \\ Новый Орлеан, Луизиана, США
}

\begin{abstract}
Русские связи с азиатскими народами и культурами представляют тему, границь которой еще не исследованы, особенно во взаимоотношениях русской и азиатской архитектур. Как артефакт, требующий значительных ресурсов, равно как и строительного искусства, архитектура базируется на множестве факторов, имеющих отношение к общественной, экономической и культурной истории. Настоящая статья отмечает специфические примеры в сибирской церковной архитектуре XVIII века, которые указывают на восприимчивость России к восточноазиатскому декору. Вероятно, рост торговли с Восточной Азией (особенно с Китаем) создал возможности для заимствований в архитектуре, в частности декоративных мотивов, которые могли распространяться в печатной форме.

Ключевые слова: сибирская иерковная архитектура, архитектура в стиле барокко, Тобольск, Иркутск, Енисейск, Бурятия, Красноярск, буддистская визуальная культура, русскокитайская торговля, Иван Бечевин.
\end{abstract}

Научная специильность: 24.00.00 - культурология. 